Article

\title{
Late Ordovician Mafic Magmatic Event, Southeast Siberia: Tectonic Implications, LIP Interpretation, and Potential Link with a Mass Extinction
}

\author{
Andrey K. Khudoley ${ }^{1,2, *}$, Andrei V. Prokopiev ${ }^{3}$, Kevin R. Chamberlain ${ }^{2,4}$,

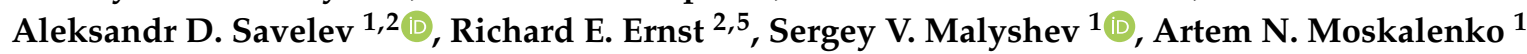 \\ and Olga Yu. Lebedeva ${ }^{6}$ \\ 1 Institute of Earth Sciences, St. Petersburg State University, Universitetskaya nab. 7/9, \\ 199034 St. Petersburg, Russia; aleksandr.d.savelev@gmail.com (A.D.S.); s.malyshev@spbu.ru (S.V.M.); \\ artemmn@gmail.com (A.N.M.) \\ 2 Faculty of Geology and Geography, Tomsk State University, 36, Lenin Prosp., 634050 Tomsk, Russia; \\ KChamber@uwyo.edu (K.R.C.); Richard.Ernst@ernstgeosciences.com (R.E.E.) \\ 3 Diamond and Precious Metal Geology Institute, Siberian Branch, Russian Academy of Sciences, Lenin Av. 39, \\ 677980 Yakutsk, Russia; prokopiev@diamond.ysn.ru \\ 4 Department of Geology and Geophysics, University of Wyoming, 1000 E. University Ave., Department 3006, \\ Laramie, WY 82071, USA \\ 5 Department of Earth Sciences, Carleton University, Ottawa, ON K1S 5B6, Canada \\ 6 A.P. Karpinsky Russian Geological Research Institute, Sredniy pr., 74, 199106 St. Petersburg, Russia; \\ Olga_Lebedeva@vsegei.ru \\ * Correspondence: a.khudoley@spbu.ru; Tel.: +7-921-7573876
}

Received: 22 November 2020; Accepted: 8 December 2020; Published: 10 December 2020

\begin{abstract}
A geochronological, isotopic, and geochemical study of the Suordakh event of mafic magmatic intrusions on the southeast Siberian margin was undertaken. U-Pb baddeleyite dating of a mafic sill intruding lower Cambrian rocks, yielded a $458 \pm 13$ Ma emplacement age. The chemical composition and stratigraphic setting of this dated sill differed from that previously attributed to the Suordakh event, implying that additional intrusions, previously mapped as Devonian, potentially belonged to the Suordakh event. No correlation between L.O.I. and concentration of highly mobile major and trace elements was documented, showing small or no influence of hydrothermal alteration on the chemical composition of the intrusions. A new tectonic reconstruction located an island arc and active margin relatively close to the study area. However, all samples had chemical compositions close to that of OIB and did not display Ta-Nb and Ti-negative anomalies, nor other features typical for subduction-related magmatism. The major and trace element distribution was most characteristic of within-plate basalts with the mantle source composition being transitional from spinel to garnet lherzolite. Combining four U-Pb baddeleyite dates of mafic sills and dykes from southeast Siberia, the age of the Suordakh event was estimated at $454 \pm 10 \mathrm{Ma}$. The area of the Suordakh event was at least $35,000-40,000 \mathrm{~km}^{2}$ (an estimate including sills previously interpreted as Devonian), and could be increased with additional dating in Southeastern Siberia. Similar ages for within-plate intrusions were reported from South Korea, West Mongolia, South Argentina, North Iran and Northwest Canada, and these ca. $450 \mathrm{Ma}$ ages were collectively close in timing with the latest Ordovician (Hirnantian) mass extinction. More high-precision dating is necessary to fully test a link between the Suordakh event (and the other age-correlative events) and the end-Ordovician mass extinction.
\end{abstract}

Keywords: U-Pb baddeleyite dating; Suordakh event; geochemistry; $\mathrm{Nd}$ and $\mathrm{Sr}$ isotopic composition; LIP; Late Ordovician mass extinction 


\section{Introduction}

The southeastern margin of the Siberian Craton is commonly known as a passive margin with well-recognized early Neoproterozoic (ca. 1000-950 Ma) and Middle-Late Devonian rifting events associated with mafic magmatism, normal faulting, and deposition of clastic rocks and evaporites [1-4]. In contrast to these events, most of the Ordovician and Silurian are reported as a period of tectonic quiescence, with deposition of thick units of carbonates with numerous fossils and reef-like build-ups [3-6]. However, U-Pb baddeleyite dating of a small mafic sill cutting an Ediacaran (Vendian) sedimentary succession for the first time, identified a Late Ordovician mafic magmatic event commonly known as the Suordakh $[7,8]$. Subsequent studies showed that the dykes and sills of the Ordovician age had specific chemical fingerprints [9,10], but the distribution and duration of the magmatic event were still not clear. Moreover, recent tectonic reconstructions [11] located an island arc of similar age nearby, thus leading to uncertainty regarding the tectonic setting of the Suordakh event-extension or subduction related.

During the past decades mafic intrusive and volcanic events of similar age were also documented in South Korea [12], Mongolia [13], Northern Iran [14], South America [15,16], and Canadian Cordillera [17], pointing to the world-wide distribution of the Late Ordovician mafic magmatism. Global environmental changes and mass extinctions triggered by gigantic magma eruptions occupy a majority of the geological literature ([18-20] and references therein). The main objective of this paper is to discuss new data on the age and distribution of Suordakh mafic magmatic event, modified interpretation of the tectonic evolution of the eastern margin of the Siberian Craton and its possible relationship with the Ordovician-Silurian boundary mass extinction. To support our interpretation, we present new geochronological, isotopic, and chemical data.

\section{Geological Setting and Petrography}

The eastern margin of the Siberian Craton is marked by a set of thrusts separating it from the Verkhoyansk Fold and Thrust Belt (Verkhoyansk FTB). The outer part of the latter consists of several segments where the southernmost part is commonly known as the South Verkhoyansk segment [21,22]. The study area is located in the western part of this segment, within the Sette-Daban Range (Figure 1).

The stratigraphy and structure of the Sette-Daban Range are discussed in many studies $([1,3,4,22]$ and references therein). Here, the Verkhoyansk FTB is separated from the Siberian Craton by the Kyllakh Thrust (Figure 1). An imbricate thrust fan with narrow tight hanging wall anticlines and wide gentle footwall synclines is the predominant structural style for most of the Sette-Daban Range [21-23]. However, to the north, several thrusts pinch out, forming the wide Gornostakh Anticline with a gentle $\left(10^{\circ}-15^{\circ}\right.$ dip angle) west limb and a much steeper $\left(40^{\circ}-50^{\circ}\right.$ dip angle) east limb. In the eastern part of the Sette-Daban Range, transpression zones with sinistral strike-slip faults and flower-like thrust structures are typical [4]. Formation of the Verkhoyansk FTB was induced by the Kolyma-Omolon microcontinent-Siberian craton collision that began in Late Jurassic, with westward progradation of deformation [21,22]. The age of granite intrusions cutting fold-and-thrust structures just to the east from the Sette-Daban Range varies from $123 \pm 1$ Ma to $94 \pm 1.4$ Ma [6,24]. However, Ar-Ar dating of metamorphic mica and a fission track study showed that deformation occurred from ca. $160 \mathrm{Ma}$ to at least $70 \mathrm{Ma}[24,25]$. 


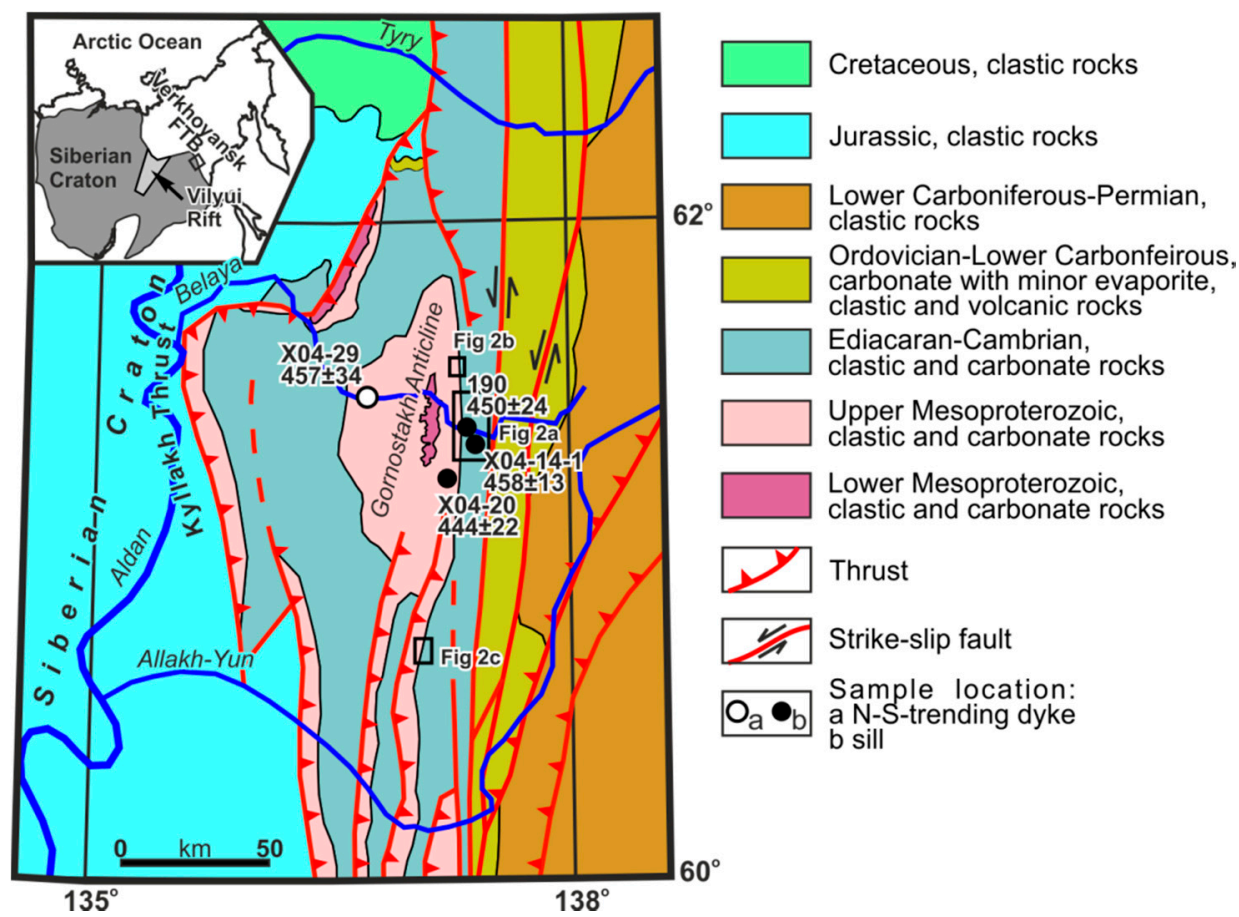

Figure 1. Simplified geological and sample location map of the central part of Sette-Daban Range and surrounding areas (geology after [22,26], simplified and modified). Data source for locations and age of intrusions: \#190, $450 \pm 24$ Ma [8], \#X04-29, $457 \pm 34$ Ma [9], \#X04-20, $444 \pm 22$ Ma [10], X04-14-1, $458 \pm 13 \mathrm{Ma}$, this study.

The Sette-Daban Range contains the most complete Mesoproterozoic to Carboniferous sedimentary succession within the eastern margin of the Siberian Craton. Three major subdivisions in the sedimentary succession, mark the occurrence of separate sedimentary basins with eastward migrating depocenters, and reflect the major stages of tectonic evolution of the eastern margin of the Siberian Craton [2-4].

The lower Mesoproterozoic succession is exposed in the core of the Gornostakh Anticline and in the hanging wall of the northern branch of the Kyllakh Thrust, where it consists of clastic and carbonate rocks formed in variable depositional environments [27]. These units are unconformably overlain by a Mesoproterozoic succession that consists of several unconformity-bounded, kilometer-scale, clastic-carbonate cycles deposited in shallow-marine environments. The uppermost unit of the Mesoproterozoic succession (Uy Group) consists of clastic rocks, part of which show evidence for slope deposition. In the easternmost exposures, mafic volcanic rocks are also documented. The total thickness of Mesoproterozoic rocks is estimated at 12-14 km [1,23,27].

The Ediacaran (Vendian) Lower Devonian succession unconformably overlies the Mesoproterozoic units, locally truncating the pre-Ediacaran folds and thrusts [1,4]. Carbonate rocks with shale units and interbeds predominate. To the west from the Gornostakh anticline, only shallow-marine Ediacaran to Ordovician rocks are exposed, whereas to the east, slope to basinal environments predominated in the Cambrian and Early Ordovician. Middle Ordovician to Lower Devonian rocks consist mainly of massive shallow-marine carbonates. The total thickness of Ediacaran-Lower Devonian rocks is estimated at approximately $11 \mathrm{~km}[1,23]$.

The Middle Devonian to Jurassic succession consists of carbonate and clastic rocks with mafic volcanic and evaporite units in its lower (Devonian) part. Overlying upper Lower Carboniferous to Jurassic rocks are represented only by the siliciclastic units collectively known as the Verkhoyansk Complex, and deposited in several Mississippi-size submarine fan-delta systems [2,23]. The total thickness of the Verkhoyansk Complex is estimated at 14-16 km [3,23].

According to common interpretations, deposition occurred on a wide passive margin, although most Mesoproterozoic rocks were likely deposited in an intracratonic basin [2,3,27]. Three rifting 
events of early Neoproterozoic, early Cambrian, and Middle-Late Devonian ages are recognized. The early Neoproterozoic and Middle-Late Devonian rifting events are associated with major mafic magmatic events, the 1000-950 Ma Sette-Daban event and 370-360 Ma Yakutsk-Vilyui LIP [1-4,28-31]. Mafic intrusions associated with the early Cambrian rifting are widely distributed on the northeast margin of the Siberian Craton and are collectively known as the Kharaulakh event [10]. Mafic sills and dykes that locally cut Carboniferous and Permian sedimentary rocks of the Verkhoyansk Complex are associated with the ca. 250 Ma Siberian Traps LIP [2,3].

A wide range of $\mathrm{K}-\mathrm{Ar}$ whole-rock ages from the mafic sills and dykes could suggest an early Paleozoic mafic magmatic event(s). However, almost all mafic intrusions that cut Mesoproterozoic and lower Paleozoic rocks were mapped as Neoproterozoic or Devonian $[1,5,26,29]$. More recently, conventional and SIMS U-Pb baddeleyite dating, yielded the ages of $450 \pm 24$ Ma (sample \#190) and $444 \pm 22 \mathrm{Ma}$ (sample \# X04-20) for mafic sills, and an age of $457 \pm 34 \mathrm{Ma}$ (sample \# X04-29) for a N-S trending mafic dyke (errors at $2 \sigma$ level [8-10]) and support recognition of an Ordovician mafic magmatic event termed the Suordakh magmatic event $[7,10]$. These intrusions are located within the Gornostakh Anticline and cut Mesoproterozoic to Cambrian rocks (Figure 1). Study of chemical and isotopic compositions showed that Ordovician intrusions are characteristically enriched in $\mathrm{TiO}_{2}$ $(3.5-5.8 \%), \mathrm{K}_{2} \mathrm{O}(0.6-1.8 \%), \mathrm{P}_{2} \mathrm{O}_{5}(0.3-1.0 \%)$, have distribution of trace elements close to that of ocean island basalts (OIB) with some enrichment in heavy rare earth elements (HREE) and $\varepsilon_{\mathrm{Nd}}(\mathrm{t})$, ranging from +3.6 to +6.5 [10]. A negative Sr anomaly was interpreted as a result of hydrothermal alteration. Most intrusions with such chemical and Nd isotopic composition are mafic sills that cut Ediacaran rocks. Mafic rocks intruding Ediacaran and lower Paleozoic rocks with different chemical composition were interpreted to be Middle to Late Devonian in age $[5,10,26,29]$.

New samples of the Suordakh mafic intrusions were mostly collected from mafic sills that cut Ediacaran rocks on the east limb of the Gornostakh Anticline (Figure 2). Two samples (L15-14 and L15-15, Figure 2b) are from an E-W trending dyke, which cuts the Ediacaran rocks and has a chemical composition close to that of typical Ordovician intrusions. One sample (L15-19) is from the same N-S-trending dyke as X04-29, which is located on the west limb of the Gonostakh Anticline (Figure 1). Two more samples from mafic sills intruding the Cambrian rocks (X04-14-1, AS18-17) were added after new U-Pb baddeleyite dating of the sample X04-14-1 discussed in this paper. To make discussion of the chemical and isotopic composition of the Ordovician intrusions more complete, we also included information from the previously studied intrusions [10]. Coordinates of all samples included in this study are listed in the Supplementary Materials (Table S1).

Ordovician mafic sills are most widespread on the east limb of the Gornostakh Anticline (Figures 1 and 2). All studied mafic sills are composed of fine to medium-grained dolerite (Figure 3) and vary in thickness from a few meters to approximately $50 \mathrm{~m}$. Host rock alteration zone is up to 2-3 $\mathrm{m}$ thick and is represented by hornfels and marble. The least-altered samples had ophitic and poikilophitic textures and consisted mainly of plagioclase (40-60 modal\%), clinopyroxene (25-45\%), Fe-Ti oxides (up to 10-15\%), and locally, olivine (0-10\%) and minor biotite, apatite and opaque minerals. Hydrothermal alteration is typically represented by replacement of plagioclase with albite, and replacement of albite by sericite, chlorite, and carbonate [10]. Hydrothermal quartz, hornblende, epidote, and chalcedony are also locally developed. The abundance of hydrothermally-derived minerals varies from 15 to $70 \%$. 

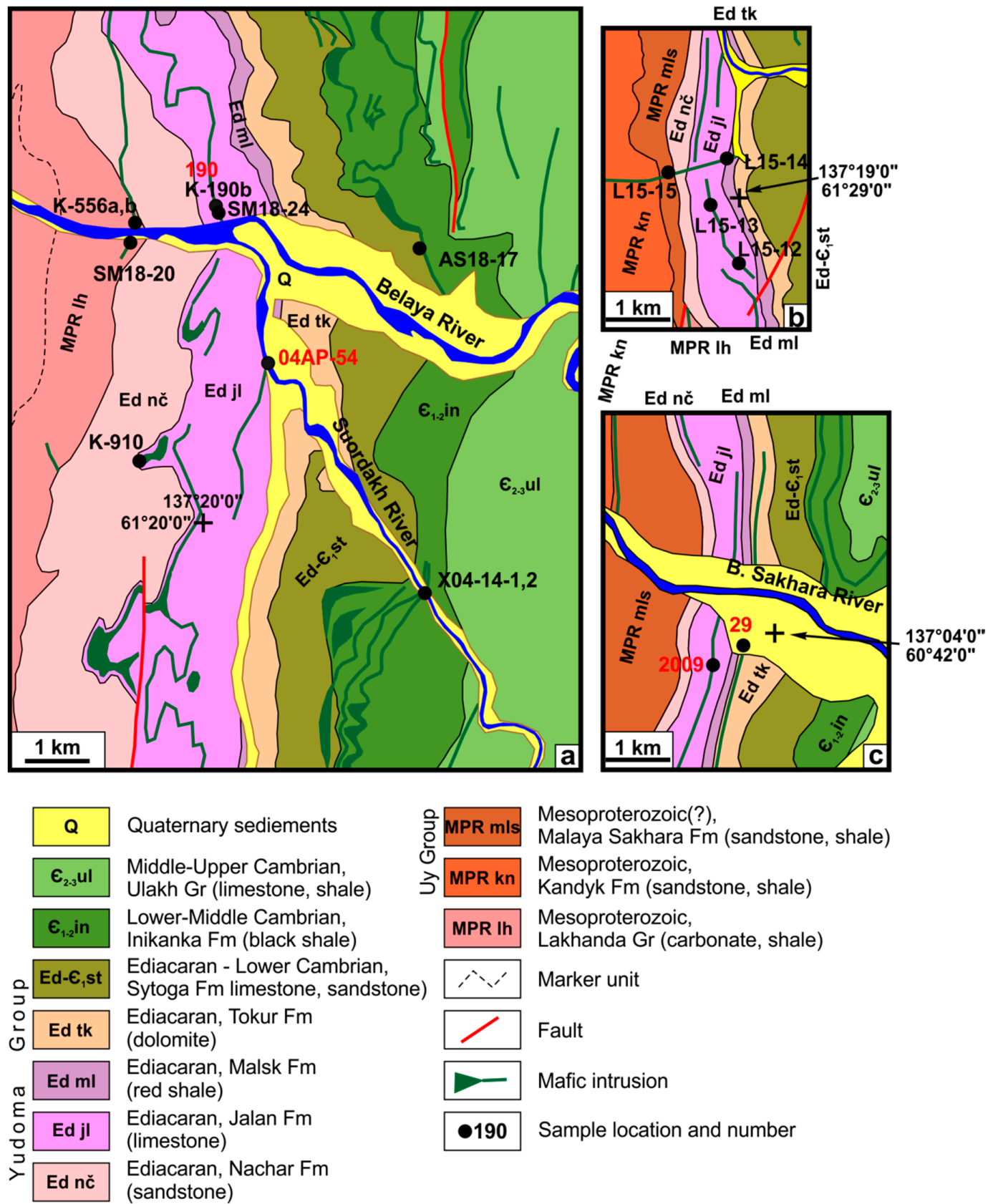

Quaternary sediements

Middle-Upper Cambrian, Ulakh Gr (limestone, shale)

Lower-Middle Cambrian,

Inikanka Fm (black shale)

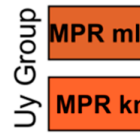

Mesoproterozoic(?)

Malaya Sakhara Fm (sandstone, shale)

Ediacaran - Lower Cambrian,

Sytoga Fm limestone, sandstone)

Ediacaran, Tokur Fm

(dolomite)
MPR Ih Mesoproterozoic
Lakhanda $\mathrm{Gr}$ (carbonate, shale)

¿', Marker unit

Ediacaran, Malsk Fm

(red shale)

Ediacaran, Jalan Fm

(limestone)

Fault

Mafic intrusion

-190 Sample location and number

Figure 2. Geological setting of the sampled intrusions of this study (geology after [32-34], modified). (a) Central part of the east limb of the Gornostakh Anticline, Belaya River area. (b) Northern part of the east limb of the Gornostakh Anticline. (c) B. Sakhara River area, see location of Figure 2a-c in Figure 1. Samples L15-14 and L15-15 are from an E-W-trending dyke, all other in Figure 2 are from sills. Samples with red numbers are from [10], samples with black numbers are from this study. Locations of samples X04-20 and X04-29 are shown in Figure 1, sample L15-13 is from the same dyke as X04-29 (N-S-trending dyke). 

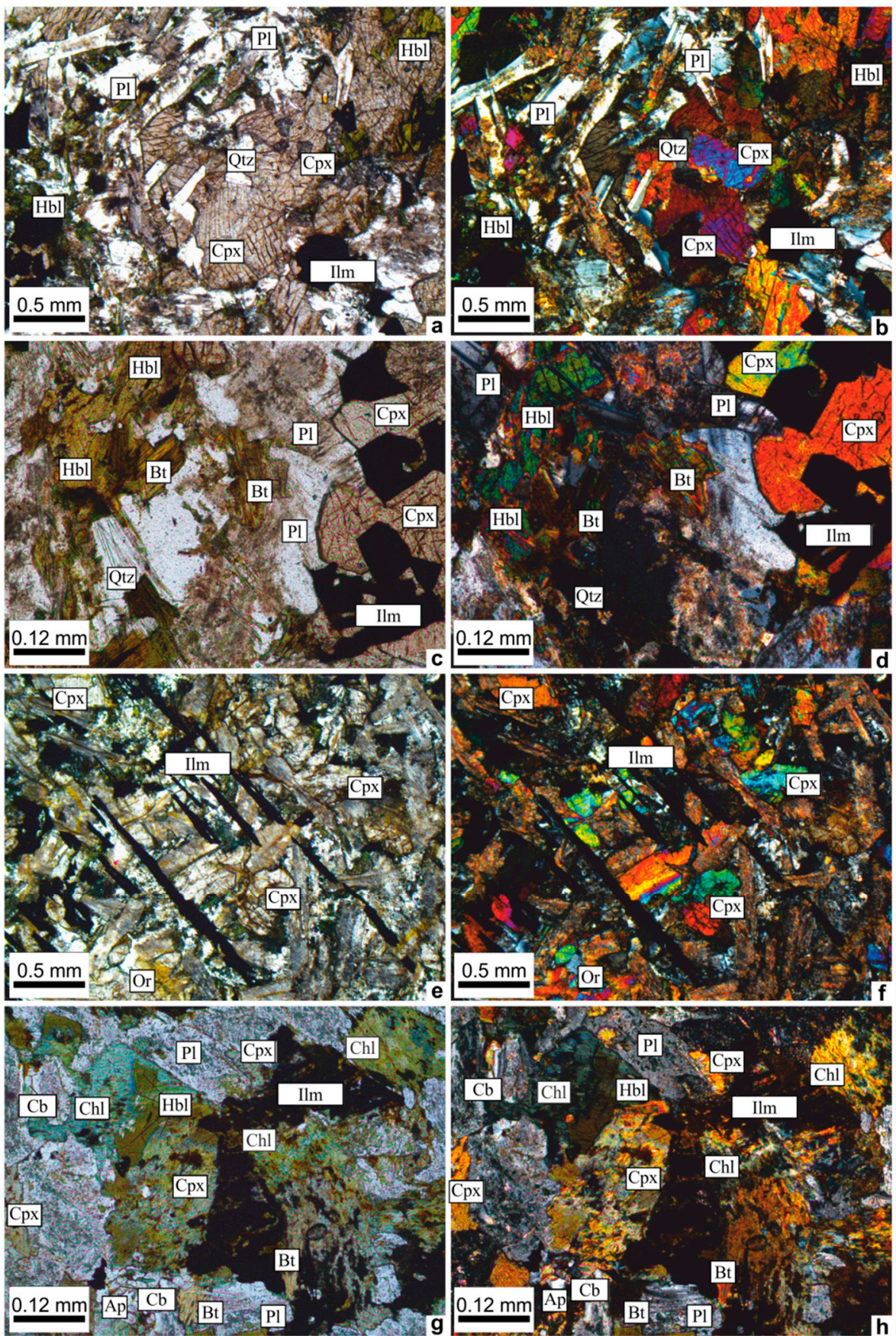

Figure 3. Microphotographs of (a-d) low-altered dolerite dyke L15-19 (the same dyke as X04-29) and (e-h) high-altered dolerite sill L15-13. See location in Figures 1 and 2. In both samples, plagioclase (Pl) is replaced by chlorite $(\mathrm{Chl})$ and carbonate $(\mathrm{Cb})$, whereas clinopyroxene $(\mathrm{Cpx})$ is replaced by hornblende

$(\mathrm{Hbl})$ and biotite (Bt). Other minerals: Ap—apatite, Ilm—ilmenite, Qtz-quartz, and Or-orthoclase.

\section{Analytical Methods}

\subsection{In Situ SIMS U-Pb Baddeleyite Dating}

Baddeleyite grains were located in polished thin sections through automated x-ray mapping, using wave dispersive spectroscopy (WDS) on the JEOL electron microprobe at the University of Wyoming (UW). Manual analysis by energy dispersive spectroscopy (EDS) and back-scattered electron imaging (BSE), using the scanning electron microscope (SEM) at UW, determined the sizes and shapes of the baddeleyite grains and whether there were any complex replacement textures with zircon. 
Target-rich subsections, approximately $8 \times 8 \mathrm{~mm}$, were cut out with a thin kerf diamond saw and mounted in $25.4 \mathrm{~mm}$ epoxy disks, along with pre-polished epoxy blocks of reference baddeleyites.

Isotopic $\mathrm{U}-\mathrm{Pb}$ measurements were performed during 3 sessions using two different secondary ionization mass spectrometers (SIMS) at UCLA, a CAMECA 1270ims and CAMECA1290-HR. The 1270 employs an $\mathrm{O}^{-}$primary source with a spot size of approximately 20 microns. A field aperture was used to reduce the sampling region to the inner third of the pit. The 1290 has a Hyperion ion source that generates a primary $\mathrm{O}_{2}^{-}$ion beam that is approximately $1-2$ microns in diameter. The beam was rastered over $3 \times 3$ micron areas for analysis to lengthen the sputtering time and to average the domains over small regions. U-Pb calibration (rsf, relative sensitivity factor) used $\mathrm{UO}_{2} / \mathrm{U}$ from Phalaborwa and Duluth gabbro baddeleyite standards (2060 Ma, $1099 \mathrm{Ma}$, respectively) and a linear model was calculated using the in-house ZIPS software. Concordia, and the weighted mean plots and calculations used IsoplotEx, based on the algorithms of Ludwig [35,36]. The results of the $\mathrm{U}-\mathrm{Pb}$ isotopic study are presented in Supplementary Materials (Table S2).

\subsection{Whole-Rock Major and Trace Element Measurements}

Whole-rock geochemical analyses were carried out at the All Russian Geological Research Institute (VSEGEI) in St. Petersburg, Russia. Major element concentrations were analyzed by X-ray fluorescence (XRF), using an ARL 9800 spectrometer. Concentrations of trace and rare earth element (REE) were determined by Inductively Coupled Plasma-Mass Spectrometry (ICP-MS), using an ELAN 6100 DRC ICP-MS instrument. Measured concentrations were significantly above the detection limits and analytical uncertainties were $<3 \%$ for major elements and $4-10 \%$ for trace elements and REE, except for Ni, which had an uncertainty of about $15 \%$. The precision of geochemical analyses was estimated from the repeated analyses of OU-6 and SBC-1 international standards. Measured concentrations of the major elements, trace elements, and REE with the detection limits are listed in Supplementary Materials (Table S3).

\subsection{Whole-Rock Sm-Nd and Rb-Sr Isotope Measurements}

Nd isotope analyses for samples AS18-17, SM18-20, and SM18-24 were performed on a Finnigan MAT 262 mass spectrometer at the Geological Institute of the Kola Science Center RAS (Apatity, Russia), using the method described in [37]. During the course of this study, the mean value of the ${ }^{143} \mathrm{Nd} /{ }^{144} \mathrm{Nd}$ ratio in the JNdi-1 standard was $0.512075 \pm 31(\mathrm{~N}=5)$. Isotope ratios were normalized to ${ }^{146} \mathrm{Nd} /{ }^{144} \mathrm{Nd}=0.7219$, and adjusted to the JNdi-1 standard with ${ }^{143} \mathrm{Nd} /{ }^{144} \mathrm{Nd}=0.512115$ [38]. Total blank measurements during the analyses were $0.3 \mathrm{ng}$ in $\mathrm{Nd}$ and $0.06 \mathrm{ng}$ in Sm. The analytical error $(2 \sigma)$ of $\mathrm{Sm}$ and $\mathrm{Nd}$ concentration measurements was $\pm 0.5 \%$. For the ${ }^{147} \mathrm{Sm} /{ }^{144} \mathrm{Nd}$ and ${ }^{143} \mathrm{Nd} /{ }^{144} \mathrm{Nd}$ ratios, the analytical errors $(2 \sigma)$ were $0.3 \%$ and $0.005 \%$, respectively. Sample X04-14-1 was analyzed on a TRITON TI mass spectrometer (at the Institute of Precambrian Geology and Geochronology of the Russian Academy of Sciences, St. Petersburg, Russia) using a method, similar to that of [37] and described in [39]. Total blank measurements were 0.03-0.2 ng for Sm and 0.1-0.5 ng for Nd.

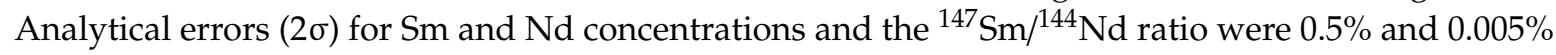
for the ${ }^{143} \mathrm{Nd} /{ }^{144} \mathrm{Nd}$ ratio. The isotopic ${ }^{143} \mathrm{Nd} /{ }^{144} \mathrm{Nd}$ ratio was normalized to a ${ }^{146} \mathrm{Nd} /{ }^{144} \mathrm{Nd}$ ratio of 0.7219 and adjusted to ${ }^{143} \mathrm{Nd} /{ }^{144} \mathrm{Nd}=0.512017$ for the JNdi-1 standard [38]. $\varepsilon_{\mathrm{Nd}}(\mathrm{t})$ values for all samples were calculated using the present-day ratios of ${ }^{143} \mathrm{Nd} /{ }^{144} \mathrm{Nd}=0.512638$ and ${ }^{147} \mathrm{Sm} /{ }^{144} \mathrm{Nd}=0.1967$ in CHUR [40].

Sr isotopes in sample X04-14-1 were analyzed on MI-1201-T mass spectrometer at the Diamond and Precious Metal Geology Institute, Siberian Branch of the Russian Academy of Sciences, Yakutsk, Russia, using the method described in [41]. Total blank measurements of the laboratory were $0.006-0.01 \mathrm{ppm}$ for $\mathrm{Rb}$ and $0.03-0.05 \mathrm{ppm}$ for Sr. Analytical errors $(2 \sigma)$ of ${ }^{87} \mathrm{Rb}$ and ${ }^{86} \mathrm{Sr}$ concentrations and ${ }^{87} \mathrm{Sr} /{ }^{86} \mathrm{Sr}$ ratio were $0.5 \%, 0.4 \%$, and $0.03 \%$, respectively. Long-term repeated measurements of the ${ }^{87} \mathrm{Sr} /{ }^{86} \mathrm{Sr}$ ratios for the Carbonate-70 Sr standard averaged $0.7089 \pm 0.0002$.

Measured $\mathrm{Nd}$ and $\mathrm{Sr}$ isotopic compositions are listed in Supplementary Materials (Table S4). 


\section{Results}

\subsection{U-Pb Geochronology of the X04-14-1 Sample}

Forty-two spots were analyzed, but the data from many showed evidence for alteration, even though only pristine grains were targeted in BSE (Figure 4 ). The data were filtered by 3 factors to identify those with the most robust geochronological information. The first filter used a Th/U cutoff $<0.3$, as $\mathrm{Th} / \mathrm{U}$ is a good indicator of minor alteration and intergrown younger zircon. Pristine baddeleyite tended to have $\mathrm{Th} / \mathrm{U}<0.1$, and often $<0.01$, whereas zircons often had $\mathrm{Th} / \mathrm{U}>1$. The second filter limited the analyses to those that were close to the range of $\mathrm{UO}_{2} / \mathrm{U}$ that were measured for the standards (Supplementary Materials, Table S2) to minimize potential errors introduced by long extrapolations of model U vs. Pb relative sensitivity factors. The U-Pb calibration was critical for the Phanerozoic dates, as it directly affected the calculated date. The third filter was \%radiogenic ${ }^{206} \mathrm{~Pb}$, which was also an indicator of alteration. For this, we used a cut-off of $>80 \%$. One spot with high $\mathrm{UO}_{2} / \mathrm{U}$ and another that had $<80 \%$ radiogenic $\mathrm{Pb}$ were kept within the robust set, as these spots still yielded dates within error of the ones that passed all 3 filters.
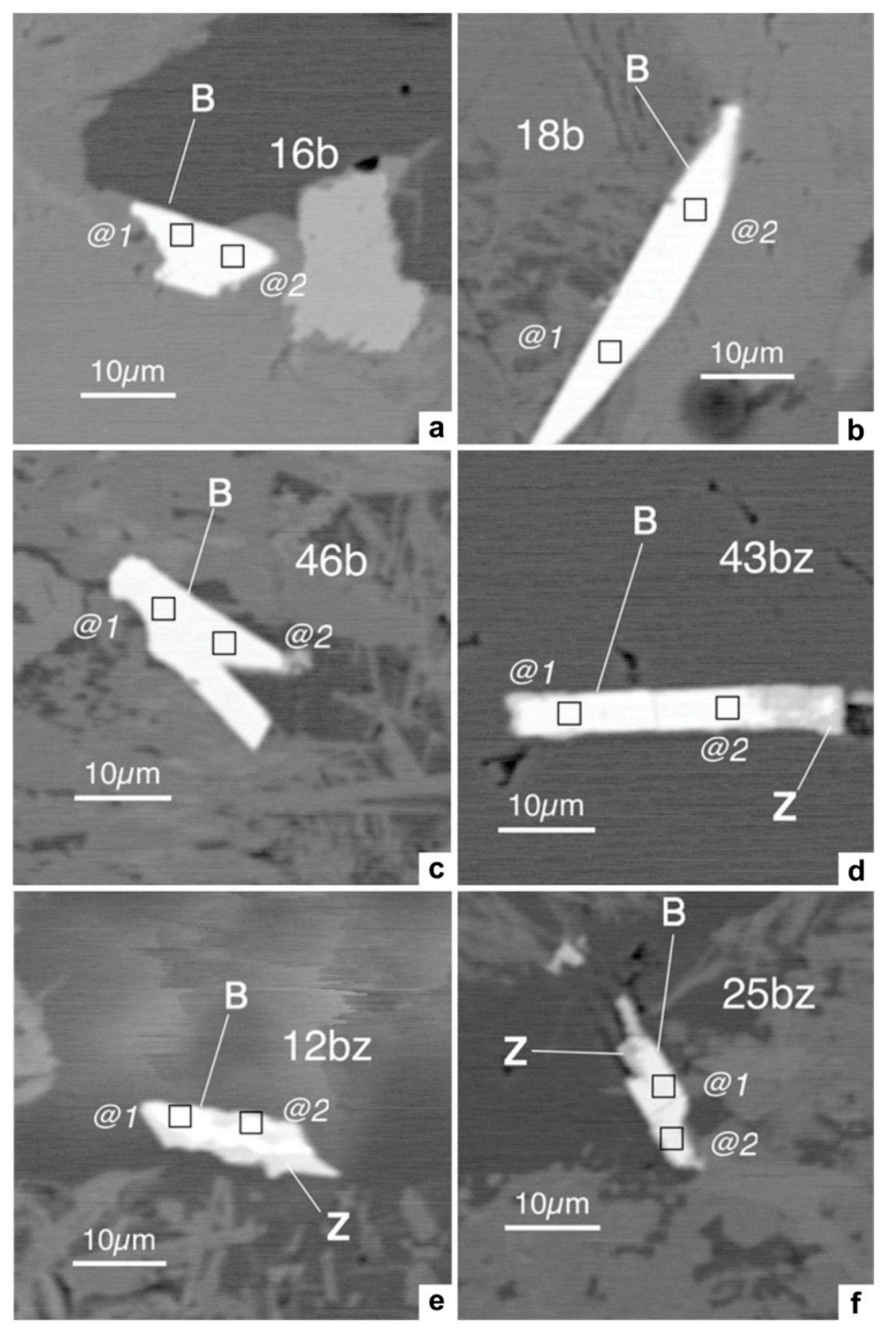

Figure 4. Back-scattered electron (BSE) images of baddeleyite (B, bright white) with varying degrees of alteration to zircon ( $\mathrm{Z}$, bright grey) from mafic sill X04-14-1. Approximate locations of the rastered analytical areas from the CAMECA1290-HR SIMS are indicated as $3 \mu \mathrm{m}$ black squares. Pristine baddeleyite domains such as in (a-d) produced robust data. Alteration to zircon in 12bz@2 (e) and both spots in $25 \mathrm{bz}$ (f) yielded poor quality data and failed the data quality filters discussed in Section 4.1. 
Ultimately 19 out of 42 spots passed these filters, and 13 of these had overlapping concordant data (Supplementary Materials, Table S2, Figure 5), whereas 6 produced younger ${ }^{206} \mathrm{~Pb} /{ }^{238} \mathrm{U}$ dates, which we interpreted to reflect the recent bulk $\mathrm{Pb}$ loss or alteration. The best estimate on the intrusive age of the X04-14-1 mafic sill was $458 \pm 13$ Ma (Figure 6, 95\% confidence, MSWD 1.16), based on the weighted mean ${ }^{206} \mathrm{~Pb} /{ }^{238} \mathrm{U}$ date of 13 analyses.

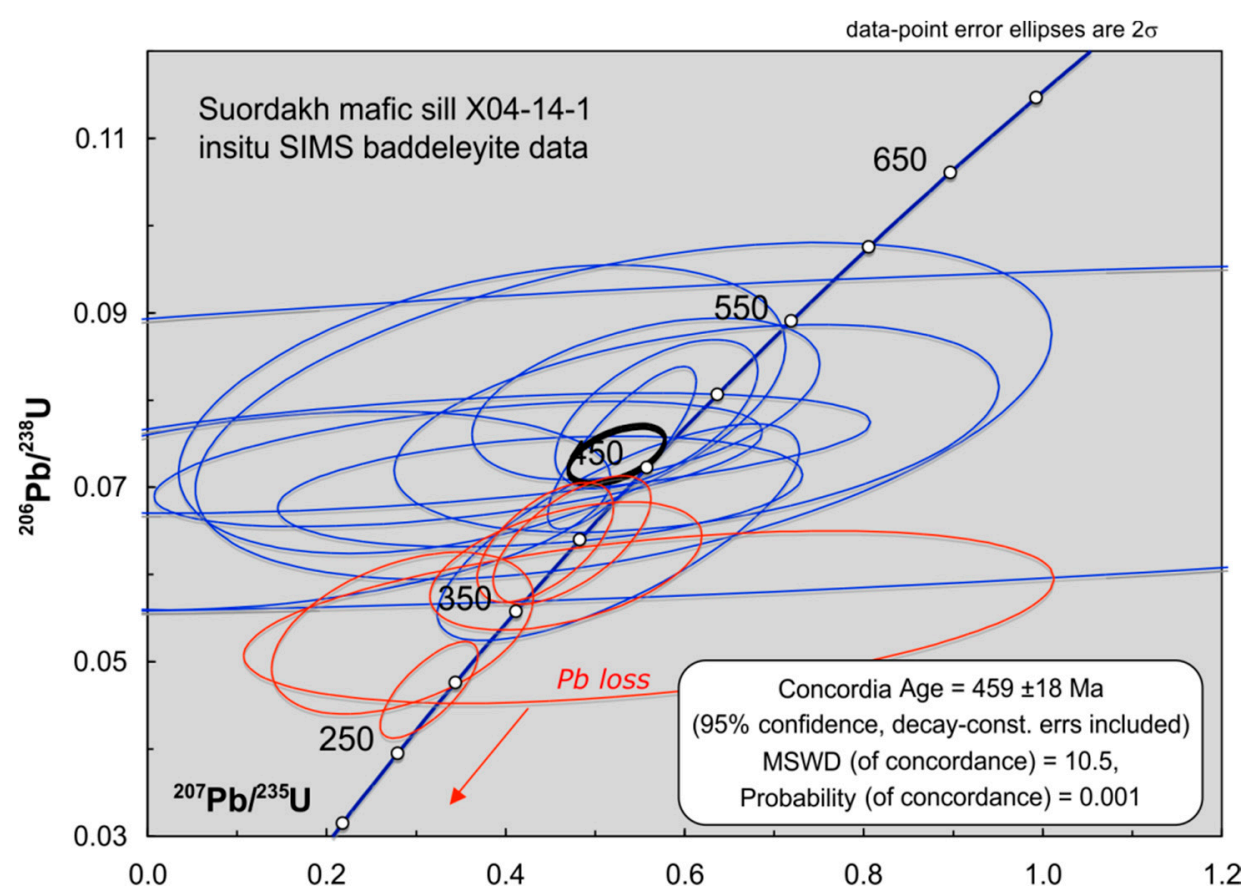

Figure 5. Concordia plot of in-situ SIMS U-Pb analyses from X04-14-1. Blue ellipses overlap Concordia and each other with a Concordia age [36] of $459 \pm 18 \mathrm{Ma}$ (small black ellipse). The red ellipses also overlap Concordia but had younger ${ }^{206} \mathrm{~Pb} /{ }^{238} \mathrm{U}$ dates and were excluded from the date calculations. These were interpreted to reflect minor, recent, bulk $\mathrm{Pb}$ loss and/or alteration.

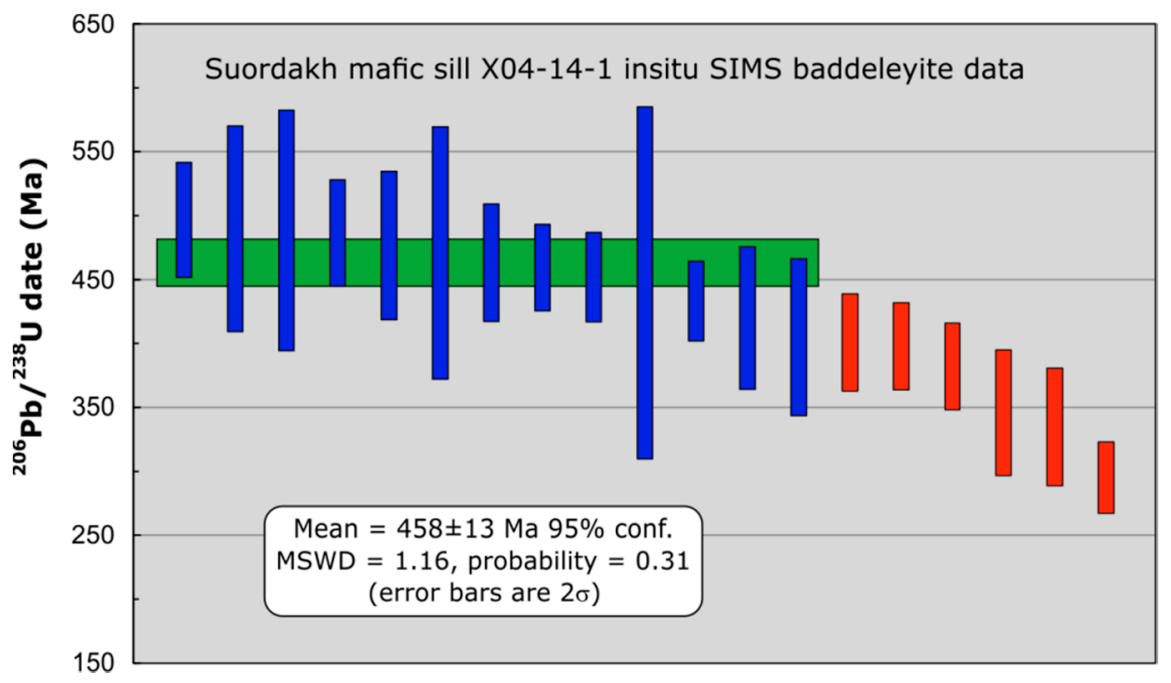

Figure 6. Plot of ${ }^{206} \mathrm{~Pb} /{ }^{238} \mathrm{U}$ dates from in-situ SIMS analyses from X04-14-1. Blue bars overlap and produce a weighted mean date of $458 \pm 13 \mathrm{Ma}$ (green box), which was interpreted as the best estimate for intrusive age. Red bars were excluded from the calculation, as their dates were younger than this mean. They were interpreted to represent $\mathrm{Pb}$ loss and/or alteration. 


\subsection{Geochemistry}

A suite of 13 new and 6 already published [10] samples of the Suordakh mafic intrusions were selected for the major and trace element analysis, and the characteristic element ratios are presented in Supplementary Materials, Table S5. Mafic intrusions display variations in $\mathrm{SiO}_{2}$ concentrations from $42.1 \%$ to $49.4 \%$, and $\mathrm{Na}_{2} \mathrm{O}+\mathrm{K}_{2} \mathrm{O}$ from $2.26 \%$ to $5.96 \%$, mainly occupying the field of basalt, with few samples in the picrobasalt and trachybasalt fields in the TAS diagram (Figure 7a). Approximately half of the samples were related to the alkali series and half to the sub-alkali series. On the $\mathrm{Zr} / \mathrm{Ti}-\mathrm{Nb} / \mathrm{Y}$ diagram, the samples occupied the same fields (Figure $7 \mathrm{~b}$ ). Although the samples from this study (cutting Cambrian age rocks) had much higher variation in the $\mathrm{TiO}_{2}$ and $\mathrm{K}_{2} \mathrm{O}$ concentrations than observed in the previous study of Suordakh intrusions cutting the Mesoproterozoic and Ediacaran rocks of the Gornostakh Anticline [10], in both classification diagrams, most samples occupied quite small fields. The data plot as mid-ocean ridge basalts (MORB) to OIB-type basalts on the V-Ti diagram and were in the tholeiitic series field on the alkali-FeO $\mathrm{tot}-\mathrm{MgO}$ diagram (Figure 8). $\mathrm{Mg \#}$ varied from 17 to 52. There was no correlation between $\mathrm{Mg \#}$ and $\mathrm{CaO}(\mathrm{r}=0.0)$, poor correlation with $\mathrm{Al}_{2} \mathrm{O}_{3}$ $(\mathrm{r}=0.3)$, and a negative correlation with $\mathrm{TiO}_{2}(\mathrm{r}=-0.5)$, likely representing the occurrence of some fractional crystallization.
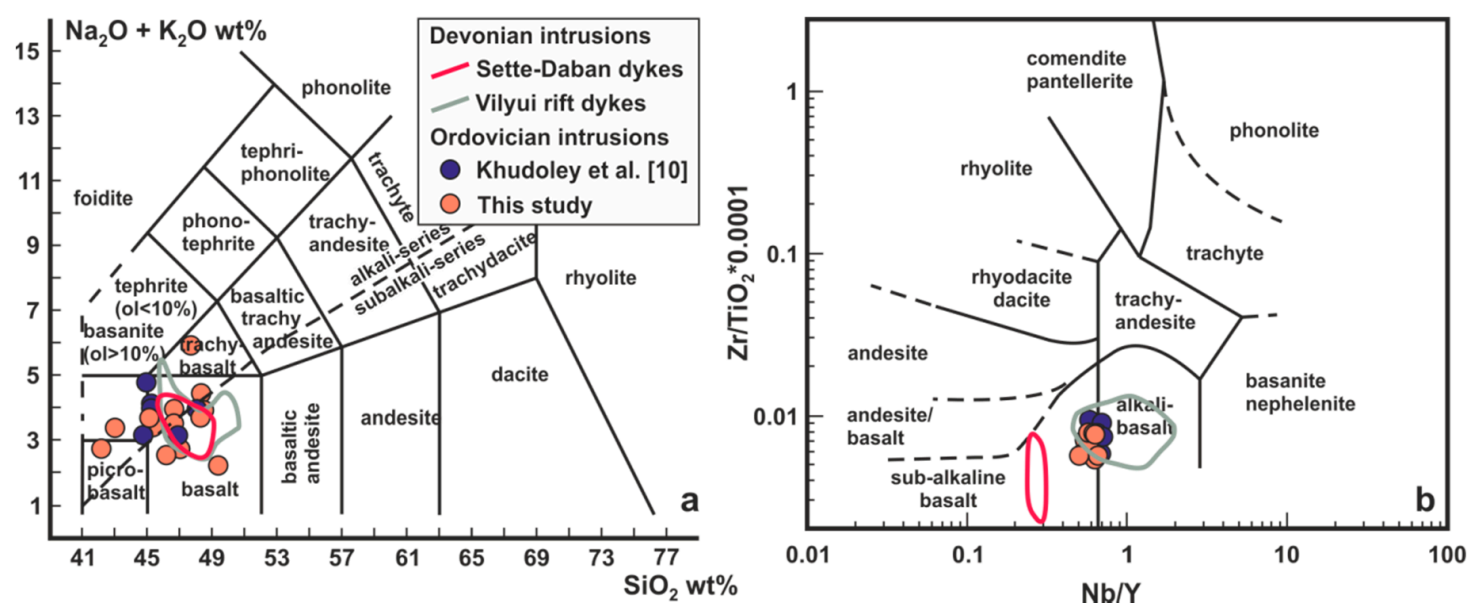

Figure 7. Classification diagrams for the Ordovician Suordakh event mafic intrusions cutting the Gornostakh Anticline [10] and those cutting Cambrian units as well (this study). (a) Total alkalis vs. silica (TAS) [42,43], (b) $\mathrm{Zr} / \mathrm{TiO}_{2}$ vs. Nb/Y [44]. Fields of the Devonian Sette-Daban dykes and Vilyui rift dykes (of the Yakutsk-Vilyui LIP) are shown for comparison, after [29,45]. See location of the Vilyui rift in Figure 1 (inset). On the TAS diagram, composition fields of the Ordovician and Devonian intrusions overlap each other, whereas on the $\mathrm{Zr} / \mathrm{TiO}_{2}$ vs. $\mathrm{Nb} / \mathrm{Y}$ diagram, the Ordovician and Devonian Vilyui rift intrusions occupy similar fields but the Sette-Daban Devonian dykes differ from them. 

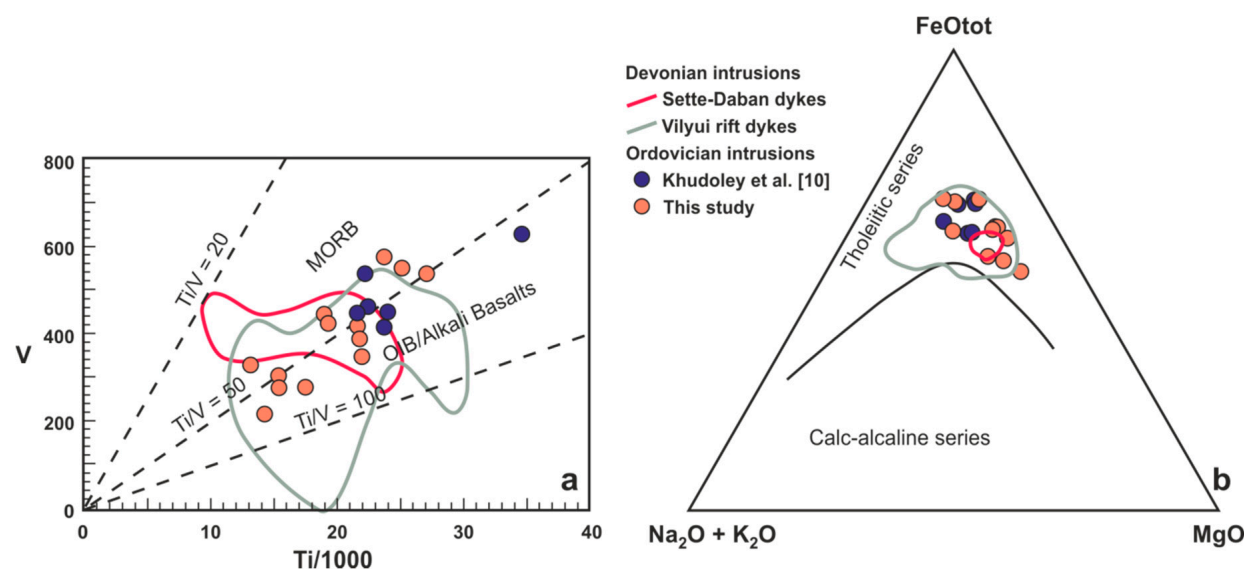

Figure 8. Discrimination diagrams for the Suordakh event mafic intrusions cutting the Gornostakh Anticline [10] and those cutting the Cambrian units as well (this study). (a) Ti vs. V [46], (b) $\mathrm{Na}_{2} \mathrm{O}+$ $\mathrm{K}_{2} \mathrm{O}-\mathrm{FeOtot} \mathrm{MgO}$ [47]. Fields of the Devonian Sette-Daban dykes and Vilyui rift dykes are shown for comparison after $[29,45]$. On both diagrams, the composition fields of the Ordovician and Devonian intrusions overlap each other.

However, highly incompatible, large ion lithophile elements (LILE) and high field strength elements (HFSE), including rare earth elements (REE), are significantly less affected by fractional crystallization than major elements, and are primarily controlled by the degree of partial melting, preserving more information on the primary magma composition [48].

On the chondrite-normalized REE distribution plot, most studied samples showed patterns intermediate between those of OIB and E-MORB (Figure 9a), with total REE concentrations that varied from 96.99 to $255.64 \mathrm{ppm}$ (Supplementary Materials, Table S5). The variation in (La/Lu)n from 3.82 to 7.53 and in $(\mathrm{La} / \mathrm{Sm}) \mathrm{n}$ from 1.85 to 2.26 , averaging at 5.1 and 2.0, respectively, were close to those reported by [10]. They represent variable enrichment of light REE (LREE) over heavy REE (HREE) and a gentle slope of the LREE distribution. The europium anomaly $\left(\mathrm{Eu} / \mathrm{Eu}^{*}\right)$ varied from 0.85 to 1.11, being negative for samples with the lowest REE concentrations (Supplementary Materials, Table S5). The distribution of other trace elements on the multi-element diagram was mainly close to that of OIB, with some variations for $\mathrm{Rb}, \mathrm{K}, \mathrm{Ba}$, Th; none or very small negative $\mathrm{Ta}-\mathrm{Nb}$ anomaly; well-expressed negative $\mathrm{Sr}$ anomaly; and none or small positive Ti anomaly (Figure 9b).
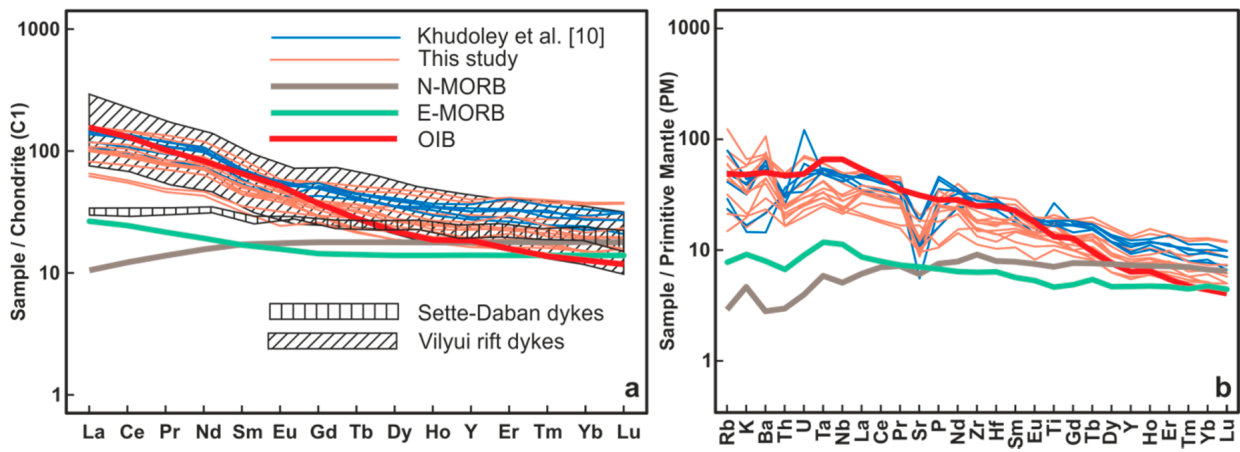

Figure 9. REE and multi-element diagrams for the Suordakh event mafic intrusions cutting the Gornostakh Anticline [10] and those cutting Cambrian units as well (this study). (a) Chondrite normalized REE diagrams. Fields of the Devonian Sette-Daban dykes and Vilyui rift dykes are shown for comparison after $[29,45]$. The Ordovician data of this study and Devonian Vilyui rift intrusions occupy the overlapping fields, whereas the Sette-Daban Devonian dykes differ from them. (b) Primitive mantle normalized diagrams for the Suordakh event mafic intrusions. Normalized using the Chondrite and Primitive Mantle composition of [49], respectively. N-MORB, E-MORB, and OIB compositions after [49]. 
The Suordakh (Ordovician) and Yakutsk-Vilyui (Devonian) events mafic intrusions occupy overlapping fields on the diagrams, based on the major elements, and cannot be separated from each other (Figures 7a and 8a,b). However, on the classification diagram based on the HFSE elements, the Devonian and Ordovician intrusions of the Sette-Daban area were clearly separated, although the Ordovician intrusions of the Sette-Daban area and Devonian dykes of the Vilyui rift occupied overlapping fields (Figure $7 \mathrm{~b}$ ). Similarly, on the REE diagrams, the Ordovician intrusions of the Sette-Daban area and the Devonian dykes of the Vilyui rift occupied overlapping fields, whereas the Devonian dykes of the Sette-Daban area differed from them through flat distribution of REE (Figure 9a).

Hydrothermal alteration is optically discernible and mainly affects plagioclase, which is widely replaced by albite, sericite, chlorite, and carbonate (Figure 3). However, in both classification diagrams (Figure 7), the studied samples occupied fields with rocks of similar composition, even though one diagram, TAS, was based on highly mobile alkalis, and the other diagram was based on immobile $\mathrm{Ti}, \mathrm{Zr}, \mathrm{Y}$, and $\mathrm{Nb}$. This relationship made significant modification of alkali concentrations unlikely. Moreover, all but 3 samples had an L.O.I. less than $2.5 \%$ and there was no correlation between L.O.I. and the concentration of mobile elements like $\mathrm{Ca}, \mathrm{Na}, \mathrm{K}, \mathrm{Rb}, \mathrm{Sr}, \mathrm{Ba}$, and $\mathrm{U}$ (Figure 10), showing no or very small influence of hydrothermal alteration on the chemical compositions of the intrusions.
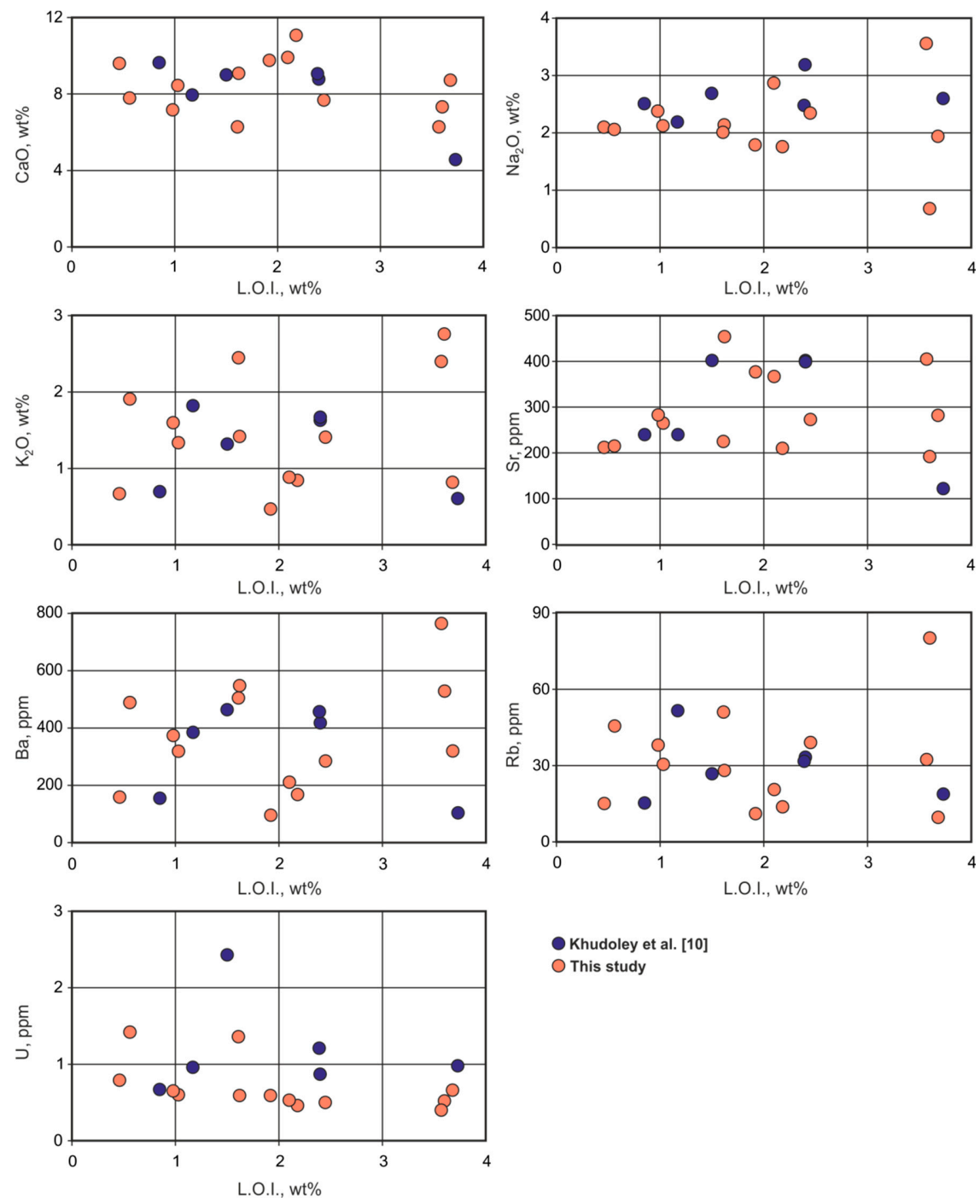

Khudoley et al. [10]

O This study

Figure 10. Plots of L.O.I. vs. mobile major and trace elements for the Suordakh event mafic intrusions cutting the Gornostakh Anticline [10] and those cutting Cambrian units, as well (this study), showing no correlation between L.O.I. and the mobile elements concentrations. 


\subsection{Nd and Sr Isotopic Study}

Four new $\mathrm{Nd}$ and one $\mathrm{Sr}$ isotope analyses of mafic intrusions were combined with four previously published $\mathrm{Nd}$ and $\mathrm{Sr}$ isotope analyses [10], to extend the available database. Some isotopic characteristics are presented in the Supplementary Materials (Table S5). $\varepsilon_{\mathrm{Nd}}(\mathrm{t})$ values ranged from 1.4 to 6.9 indicating a mixture of depleted and enriched sources (Figure 11a). However, the Nd isotope compositions did not show any correlation with the $\mathrm{SiO}_{2}$ contents (Figure 11b), implying that direct crustal contamination, as suggested by the range of $\mathrm{Nd}$ isotope values, was very unlikely. Sr isotope compositions also showed significant variation with the ${ }^{87} \mathrm{Sr} /{ }^{86} \mathrm{Sr}$ initial ratios, ranging from 0.7066 to 0.7081 , pointing to the enrichment in radiogenic ${ }^{87} \mathrm{Sr}$ (Figure 11c) (Supplementary Materials, Table S5) that might be a result of variable processes like crustal contamination, hydrothermal alteration, or sedimentary recycling $[50,51]$. However, the absence of a correlation between $\mathrm{Nd}$ isotopic compositions and $\mathrm{SiO}_{2}$ contents did not support crustal contamination (Figure 11b). Previously, radiogenic ${ }^{87} \mathrm{Sr}$ enrichment in the studied intrusions was interpreted as a result of hydrothermal alteration processes [10,29], but relationship between highly mobile elements and L.O.I. likely pointed to no significant influence of hydrothermal alteration on their chemical compositions (Figure 10). However, Jourdan et al. [51] reported alteration processes that affected $\mathrm{Sr}$ isotope compositions, but did not affect trace element compositions of mafic dykes. Available data on Sr isotopic compositions of the Suordakh mafic intrusions were not enough to identify reasons for radiogenic ${ }^{87} \mathrm{Sr}$ enrichment and we do not further address this question in the following discussion.
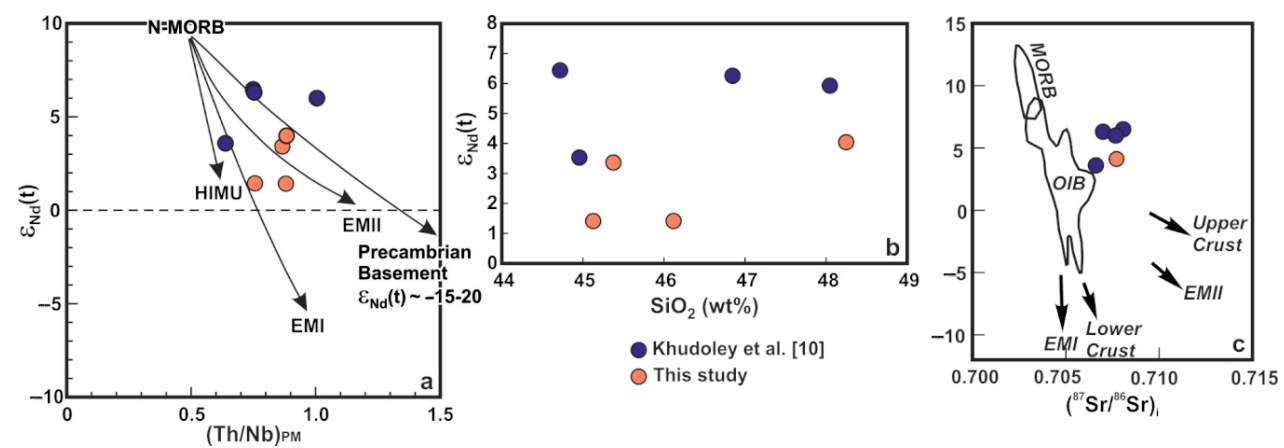

Figure 11. Nd isotope characteristics of the Suordakh event mafic intrusions cutting the Gornostakh Anticline [10] and those cutting the Cambrian units as well (this study) (a) $\varepsilon_{\mathrm{Nd}}(\mathrm{t}) \mathrm{vs}$. (Th/Nb) $\mathrm{PM}$. (b) $\varepsilon_{\mathrm{Nd}}(\mathrm{t})$ vs. $\mathrm{SiO}_{2}$. No correlation between $\varepsilon_{\mathrm{Nd}}(\mathrm{t})$ and $\mathrm{SiO}_{2}$ is shown. Primitive mantle composition (pM) is from [49], (c) $\left.{ }^{87} \mathrm{Sr} /{ }^{86} \mathrm{Sr}\right)$ i versus $\varepsilon_{\mathrm{Nd}}(\mathrm{t})$ diagram for the Suordakh event mafic intrusions (from [52,53]). EMI and EMII—enriched mantle sources; HIMU—high $\mu\left({ }^{238} \mathrm{U} /{ }^{204} \mathrm{~Pb}\right)$ mantle source.

\section{Discussion}

\subsection{Age and Distribution of the Suordakh Event Intrusions and Its Correlates and Relationship with the Late Ordovician Mass Extinction}

The weighted mean of four U-Pb baddeleyite dates of the Suordakh mafic intrusions was $454 \pm 10 \mathrm{Ma}$, which we interpreted as an estimate of the timing of the Suordakh mafic magmatic event (Figure 12). Although the distribution of the Suordakh event mafic sills was previously thought to be located predominantly within the Mesoproterozoic and Ediacaran (Vendian) rock units [10], the new dating of the X04-14-1 sample showed that the Suordakh mafic sills also cut the Cambrian rocks, significantly increasing the areal extent of this magmatic event (Figure 13). Furthermore, prior to this study, a typical feature of these ca. $450 \mathrm{Ma}$ intrusions that cut the Mesoproterozoic and Ediacaran rocks [10] was high $\mathrm{Ti}\left(\mathrm{TiO}_{2}>3.5 \%\right)$ and $\mathrm{P}\left(\mathrm{P}_{2} \mathrm{O}_{5}>0.3 \%\right)$ concentrations. However, the X04-14-1 sample had lower concentrations of both $\mathrm{Ti}\left(\mathrm{TiO}_{2}=2.37 \%\right)$ and $\mathrm{P}\left(\mathrm{P}_{2} \mathrm{O}_{5}=0.23 \%\right)$ (Supplementary Materials, Table S3). These results showed that a significant number of mafic sills cutting the Cambrian rocks or showing much lower concentrations of Ti and P might also be Ordovician. 
Distribution of the Ordovician dykes is not clear. U-Pb baddeleyite dating and the specific chemical composition showed that there were at least few Ordovician N-S-trending dykes (samples X04-29, L15-19) and E-W-trending dykes (samples L15-14, L15-15). However, all N-S-trending dykes that cut the Cambrian and Ordovician rocks to the east from the Gornostakh Anticline were supposed to be Devonian [26,29,32,34]. Trace elements composition of the Devonian dykes seemed to be different from that of the Suordakh event intrusions (Figures $7 \mathrm{~b}$ and 9a). However, the trace elements composition of the Devonian dykes was reported from only 5 intrusions and was very different from that of the synchronous dykes of the Vilyui rift [29]. More isotopic dating is necessary to identify the areal extent of the Ordovician dykes.

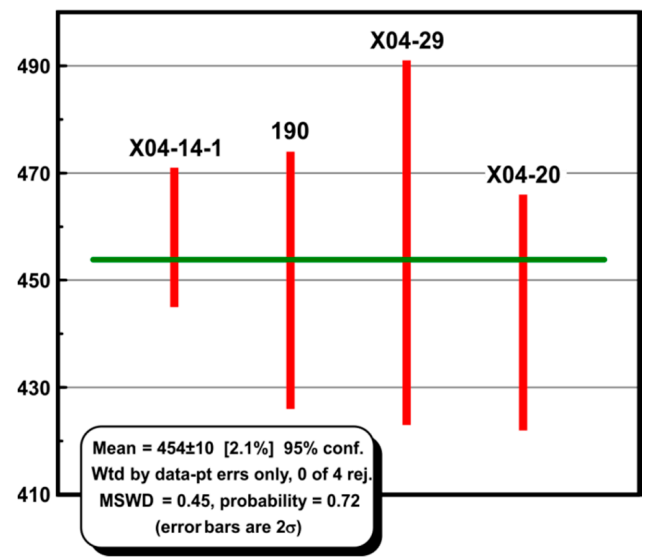

Figure 12. Weighted average of the available U-Pb baddeleyite dates of Ordovician mafic intrusions, to estimate the age of the Suordakh event.

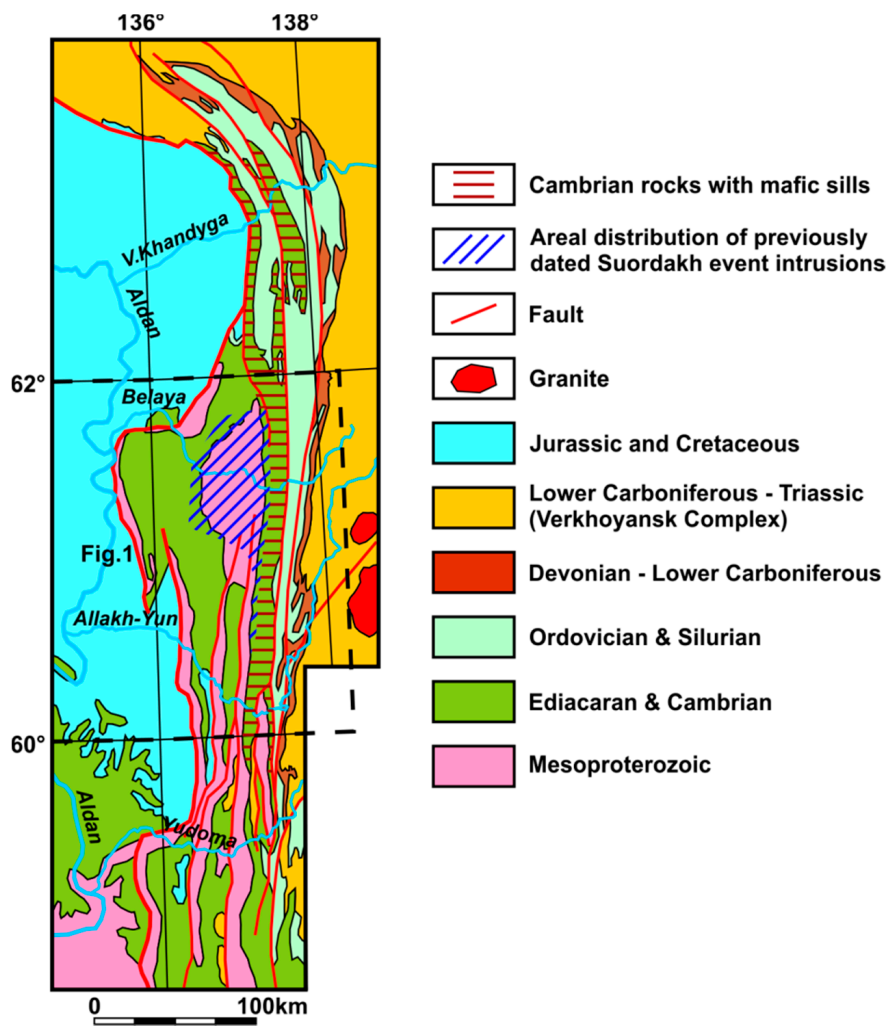

Figure 13. Areal distribution of the previously dated Suordakh event mafic intrusions [10], and their possible extent within Cambrian rocks with reference to the new U-Pb dating of the X04-14-1 mafic sill. Geology from [22,26,54]; simplified and modified. 
The areal distribution of the Suordakh event mafic intrusions in the Sette-Daban area was less than that of the $100,000 \mathrm{~km}^{2}$ minimum for classification as an LIP [7,55], including mafic sills that cut the Cambrian rocks in the Suordakh event intrusions that estimated its areal extent as $35,000-40,000 \mathrm{~km}^{2}$ (Figure 13). Based on apatite and zircon fission track data, the total erosion in this area likely reached 6-8 km [25] showing that a significant amount of mafic rocks, including, probably, mafic volcanic rocks, was removed after formation of the Verkhoyansk FTB in Mesozoic, thereby expanding the likely volume and distribution of the Suordakh rocks. The areal extent of the Suordakh event intrusions might also include regions to the east, as the Ediacaran and lower Paleozoic rocks are hidden below the younger Paleozoic rocks units (Figure 13).

Mafic intrusions and volcanic rocks correlating with the Suordakh event are found in various parts on the Earth's surface. These might have formed near SE Siberia, and together with the Suordakh event, could define a single LIP. However, given reconstruction uncertainties, these coeval intraplate units could also represent separate but coeval events [7]. In South Korea, the bimodal volcanic rocks of the Ongnyeobong Formation formed in a within-plate tectonic setting and yielded SHRIMP U-Pb zircon ages at 445.0 $\pm 3.7 \mathrm{Ma}$ and $452.5 \pm 3.2 \mathrm{Ma}$ [12,56]. CA-ID-TIMS U-Pb zircon dating of rift-related bimodal volcanic rocks of the Teel Formation in Western Mongolia, yielded a 446.03 \pm 0.21 Ma age of their eruption [13]. Within error, both the South Korean and Mongolian volcanic rocks overlapped in age with mafic intrusion from Southeast Siberia. Stratigraphic relationships suggest a Late Ordovician age for continental rift-related basalts in Andean Argentine Precordillera [15] and Late Ordovician-Silurian age for continental rift-related basalts in Northern Iran [14]. Middle Ordovician-Silurian within-plate basalts were documented in Selwyn Basin, Northwest Canada [17,31]. Although the amount of magmatic rocks documented for Southeast Siberia, South Korea, Mongolia, and other areas, could be smaller than those in a typical LIP, all together they point to ca. 450-440 Ma timing, for a globally important pulse of intraplate magmatism.

A wide distribution of either a single mafic magmatic event or multiple coeval events might trigger climate and environmental changes, glaciation, and mass extinction, which was well-documented in the latest Ordovician age (e.g., [19,57-60] and references therein). Correlation between mass extinctions and flood-basalt eruptions and related LIPs starting from the Late Permian is now well documented, e.g., the ages of flood-basalt episodes match in age with 7 out of 11 major extinction events at 66, 94, ca. 120, 183, 201, 252, and 260 Ma [7,19,61,62]. For Paleozoic time, the relationship between most mass extinctions and LIPs is recognized as well [7,63]. However, the major Ordovician-Silurian boundary extinction does not contain an obvious LIP correlate. The age of the Late Ordovician glaciation is estimated as the Hirnantian Stage, whereas mass extinction occurred mainly at the Katian/Hirnantian stages boundary (445.2 $\pm 1.4 \mathrm{Ma}$ [64]) and, probably also, at the Ordovician/Silurian boundary (443.8 $\pm 1.5 \mathrm{Ma}$ [64]). Within error, the age of the Suordakh mafic magmatic event overlap with both boundaries, making it a good candidate to trigger the environmental changes responsible for the Late Ordovician extinction [7,63]. However, more high-precision dating of magmatic rocks is necessary to test this possible link more robustly.

\subsection{Tectonic Setting and Magma Source of the Suordakh Event Intrusions}

Available paleomagnetic data as well as correlation of sedimentary successions and tectonic events show that during Mesoproterozoic - early Paleozoic — the Okhotsk and Omolon massifs with Archean to Proterozoic basement and adjoining passive margin of the Omulevka terrane composed of carbonate and clastic rocks, were likely parts of the same large continental block, along with the Siberian craton forming a Siberian paleocontinent (Figure 14) [11,65-67]. In the eastern direction, the passive margin Omulevka terrane was in contact with the Rassokha terrane, where the Ordovician rocks consisted of clastic rocks interbedded with tuffs of basalt to andesite composition, and rare basalt flows marking the approximate location of the Amandykan island arc $[11,65,68,69]$. Recent SHRIMP U-Pb zircon dating of a small granite massif with an island arc-type chemical composition, yielded a $440 \pm 2 \mathrm{Ma}$ 
age of intrusion [70]. A granite intrusion that was close in age (445.7 $\pm 1.5 \mathrm{Ma}$, SHRIMP U-Pb zircon dating) was documented on the northwest margin of the Okhotsk massif (Figure 14) [71].
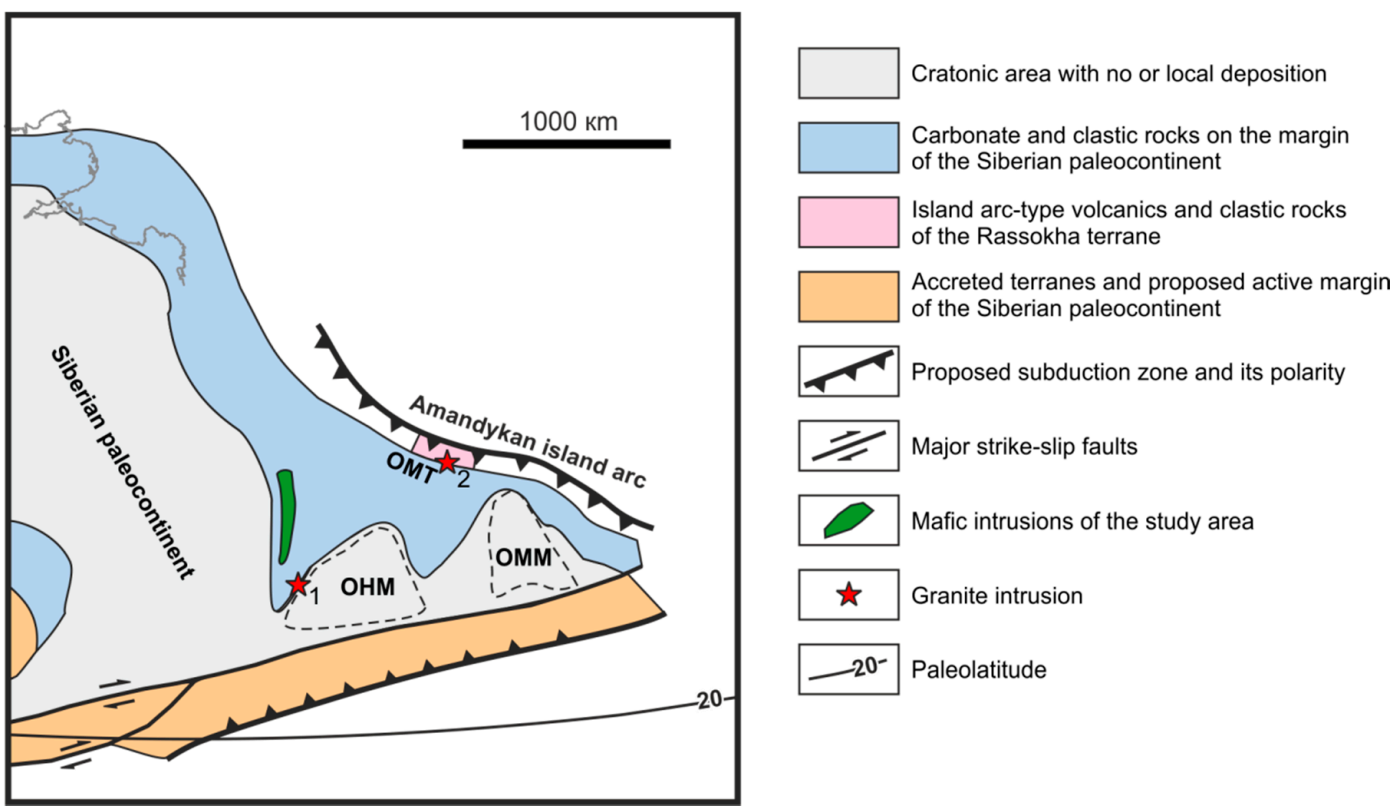

Figure 14. Paleotectonic reconstruction of the eastern part of the Siberian craton. Modified from [11]. Granite intrusions: $1-440 \pm 2 \mathrm{Ma}$ [70], 2—445.7 $\pm 1.5 \mathrm{Ma}$ [71]. OHM-Okhotsk massif, OMM-Omolon massif, and OMT-Omulevka terrane.

Combining all available data, we present a paleotectonic reconstruction where our study area with Late Ordovician mafic intrusions was surrounded by island arcs or active margins, raising questions on the tectonic setting of the southeast margin of the Siberian craton in Ordovician time (Figure 14). Traditionally, it was interpreted as a passive margin (e.g., [2-4,72]), but in view of the island arc magmatic activity, it could be interpreted as a wide, back-arc basin. If so, the mafic intrusions of the Suordakh event ( $454 \pm 10 \mathrm{Ma}$ ) and granite (445-440 Ma) might be related to the same subduction-related magmatism. However, it is also known that LIP events can have associated voluminous silicic magmatism and there can be ambiguity in distinguishing silicic magmatism associated with arcs from that associated with LIPs $[7,73]$. Chemical composition of the Suordakh event intrusions can test this arc-link hypothesis.

None of the studied samples show either Ta-Nb or Ti-negative anomalies, which are typical for the subduction-zone basalts. The $\mathrm{Nb} / \mathrm{La}$ ratio was high, varying from 0.70 to 1.30 , and averaging at 0.98 (Supplementary Materials, Table S5), which is typical for within-plate basalts not affected by contamination [52]. The distribution of HFSE and REE elements also supported the within-plate origin of the Suordakh event mafic intrusions. On the $\mathrm{Th} / \mathrm{Yb}-\mathrm{Nb} / \mathrm{Yb}$ diagram, they plot within the mantle MORB-OIB array along with Devonian Sette-Daban and Vilyui rift dykes of the Yakutsk-Vilyui LIP $[29,45]$, close to OIB and far from the field of arc basalts. They are also distinct from ca. 1000-950 Ma Neoproterozoic mafic intrusions from the same area, ca. 490-480 Ma post-orogenic intrusions from the southwest margin of the Siberian craton and 183 Ma flood basalts of the Karoo LIP (of South Africa), all of which show some influence of inherited subduction material or crustal contamination (Figure 15a) [30,51,74]. On a $\mathrm{Zr} / \mathrm{Nb}-\mathrm{Nb} / \mathrm{Th}$ diagram (Figure 15b), the studied intrusions occupy the field of oceanic plateau basalts close to the margin of OIB and out of the field of island arc basalts. According to [75], the relationship between $\mathrm{Zr}, \mathrm{Nb}$, and $\mathrm{Y}$ calculated as $\Delta \mathrm{Nb}=1.74+$ $\log (\mathrm{Nb} / \mathrm{Y})-1.92 \log (\mathrm{Zr} / \mathrm{Y})$ was sensitive to the mantle source of magma, and positive $\Delta \mathrm{Nb}$ values indicated an enriched mantle source in contrast to negative $\Delta \mathrm{Nb}$ values that are typical for the depleted mantle. Among the Suordakh event intrusions, 17 out of 19 samples demonstrated $\Delta \mathrm{Nb}>0$ 
(Supplementary Materials, Table S5). Modeling of the mantle source using REE, indicated melting in transition from spinel to garnet lherzolite mantle material, with 3-10\% of partial melting (Figure 16).
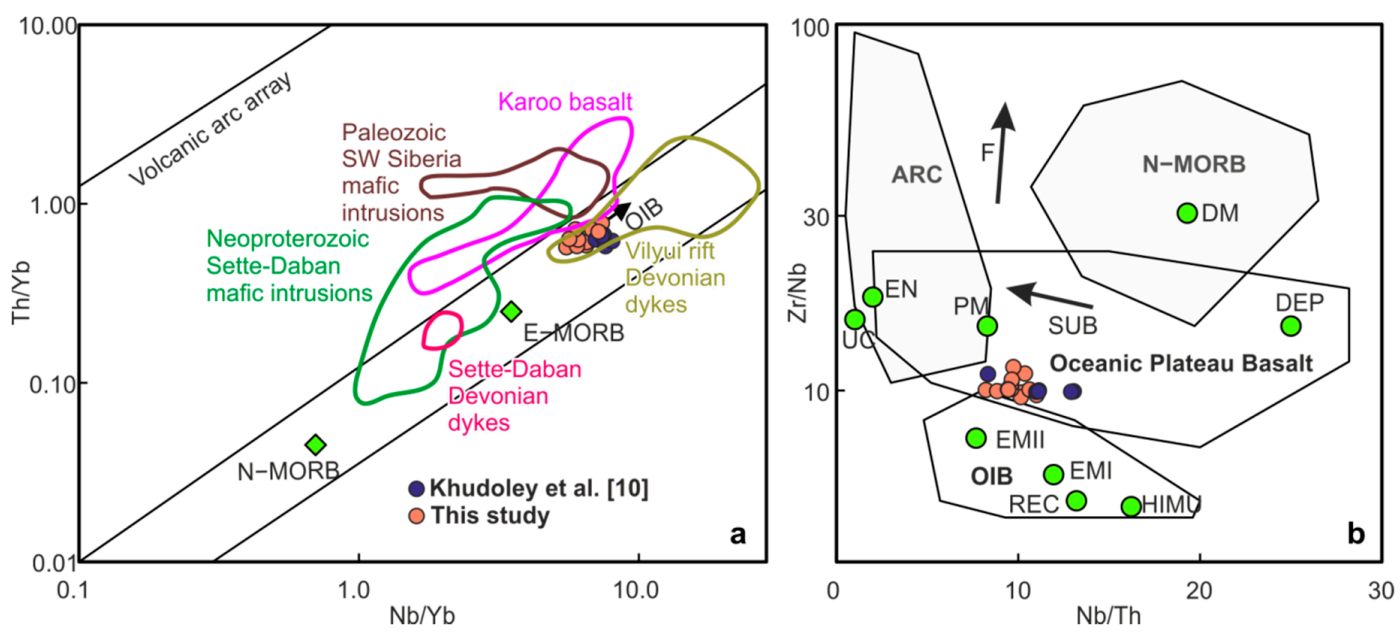

Figure 15. (a) $\mathrm{Th} / \mathrm{Yb}-\mathrm{Nb} / \mathrm{Yb}$ diagram Suordakh event mafic intrusions [76]. Data source for Devonian Sette-Daban dykes [29], Devonian Vilyui rift dykes [29,45], Karoo basalts [51], Neoproterozoic (1000-950 Ma) intrusions, SE Siberia [30], early Paleozoic intrusions, SW Siberia [74]. (b) Zr/Nb-Nb/Th plot [77]. Abbreviations: UC-upper continental crust; PM-primitive mantle; DM-shallow depleted mantle; HIMU— high $\mu\left({ }^{238} \mathrm{U} /{ }^{204} \mathrm{~Pb}\right)$ mantle source; EMI and EMII-enriched mantle sources; ARC — arc-related basalts; N-MORB—normal mid ocean ridge basalt; OIB—oceanic island basalt; DEP-deep depleted mantle; EN-enriched component; and REC-recycled component. Arrows indicate effects of batch melting (F) and subduction (SUB).

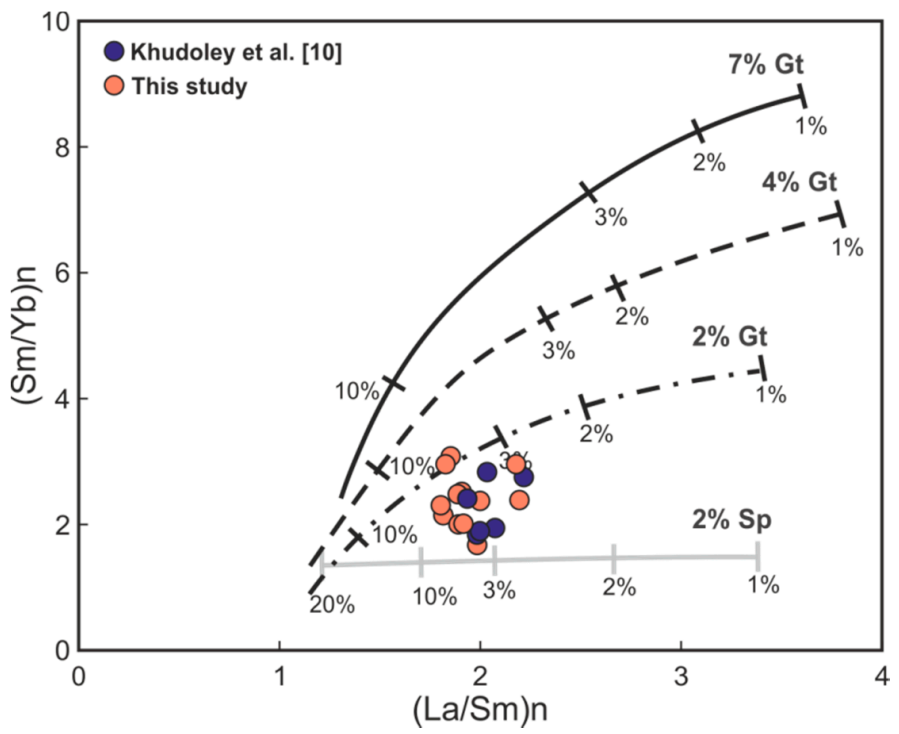

Figure 16. $(\mathrm{Sm} / \mathrm{Yb}) \mathrm{n}$ vs. $(\mathrm{La} / \mathrm{Sm}) \mathrm{n}$ diagram for the Suordakh event mafic intrusions and non-modal batch melting modeling of a lherzolitic mantle source [51]. The tick marks on the curves correspond to the melting degrees. The grey curve is the melting curve of a spinel-bearing lherzolite source, with the following modal composition: $55 \%$ olivine, $15 \%$ orthopyroxene, $28 \%$ clinopyroxene, and $2 \%$ spinel. Black curves are the melting curves of garnet-bearing lherzolite mantle sources containing $2 \%$ (dashed and dotted), $4 \%$ (dashed), and $7 \%$ (solid) modal garnet, respectively. Source modal composition is $69-64 \%$ olivine, $20 \%$ orthopyroxene, $9 \%$ clinopyroxene, and $2-7 \%$ garnet.

However, some geochemical and isotopic features might be interpreted to reflect an influence of the arc-related processes. The enrichment of LILE over the HFSE and REE elements, likely points to 
addition of aqueous fluids during magma evolution, and the $\mathrm{Ba} / \mathrm{Th}$ and $\mathrm{Sr} / \mathrm{Th}$ ratios can be used to estimate the contributions from aqueous fluids in the melting source [78,79]. On the $\mathrm{Ba} / \mathrm{Th}$ and $\mathrm{Sr} / \mathrm{Th}$ vs. Th/Nd diagrams (Figure 17) studied, the samples followed a trend pointing to possible influence of aqueous fluids on the magma composition, which in turn, might reflect subduction-related enrichment of mantle sources [79]. Variation of the $\varepsilon_{\mathrm{Nd}}(\mathrm{t})$ values from 1.4 to 6.9 , likely point to mixing of depleted and enriched sources (Supplementary Materials, Table S5). The radiogenic ${ }^{87}$ Sr enrichment might also be interpreted as an influence of the subduction processes, although magmatic rocks with similar $\mathrm{Nd}$ and Sr isotope characteristics were also reported from LIPs [29,51,52,79,80]. Moreover, continental LIPs quite often display some subduction-like signatures [7,51,52,81] and interpretation of the Suordakh event mafic intrusions, as within-plate basalts seems to be the most reasonable.
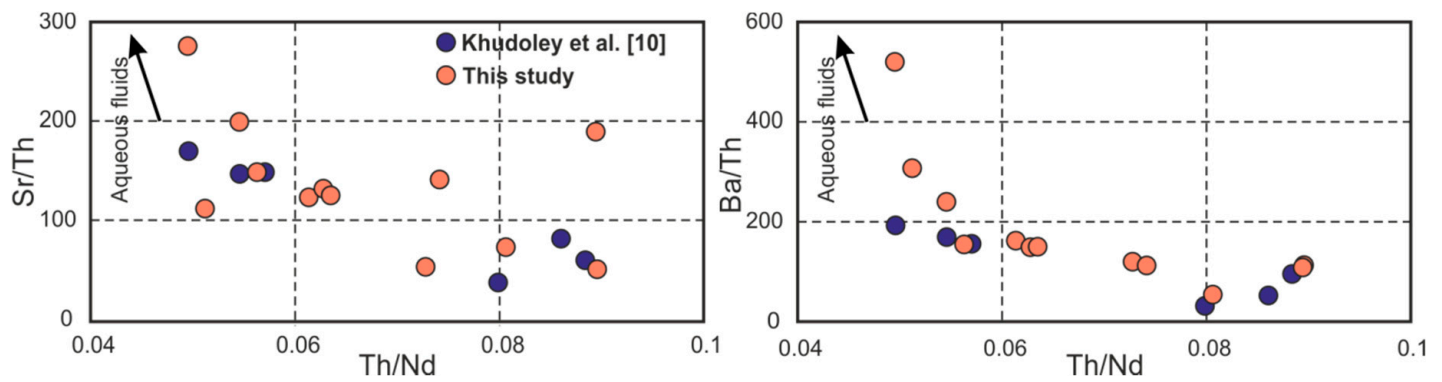

Figure 17. $\mathrm{Sr} / \mathrm{Th}$ vs. Th/Nd and $\mathrm{Ba} / \mathrm{Th}$ vs. Th/Nd diagrams for the Suordakh event mafic intrusions, showing the possible influence of aqueous fluids on the magma composition [79].

\section{Conclusions}

$\mathrm{New} \mathrm{U}-\mathrm{Pb}$ baddeleyite geochronological, chemical, and isotopic data provide new constraints on the origin and tectonic setting of the Suordakh event mafic intrusions in the Sette-Daban region of the Southeastern Siberian craton:

- $\quad$ Based on the weighted mean date of $\mathrm{U}-\mathrm{Pb}$ baddeleyite dates of 4 intrusions, the age of the Suordakh event was estimated at $454 \pm 10 \mathrm{Ma}$;

- $\quad$ New U-Pb baddeleyite dating significantly increased the possible volume of the Suordakh event intrusions to include intrusions in the Sette Daban region that have much lower $\mathrm{TiO}_{2}, \mathrm{~K}_{2} \mathrm{O}$, and $\mathrm{P}_{2} \mathrm{O}_{5}$ concentrations, than it was previously supposed by [10] and to include intrusions into the Cambrian strata;

- Within error, the ages of mafic intrusions of the Suordakh event from Southeast Siberia, overlapped with those of within-plate mafic magmatic rocks from South Korea, Western Mongolia, Southern Argentina, Northern Iran, and Northwest Canada, supporting a significant pulse of ca. 450-440 Ma intraplate magmatism, which is approximately the age of the latest Ordovician mass extinction event;

- Despite the relative close location of the Amandykan island arc and an active margin during the Ordovician, the Suordakh event mafic intrusions have chemical compositions typical of within-plate basalts.

Supplementary Materials: The following are available online at http://www.mdpi.com/2075-163X/10/12/1108/s1, Table S1. Coordinates of samples of the Suordakh event mafic intrusions; Table S2. SIMS data from in-situ analyses of baddeleyite, Suordakh mafic sill, X04-14-1 [82]; Table S3. Major (wt.\%) and trace (ppm) elements concentrations of the Suordakh event mafic intrusions; Table S4. Nd and Sr isotope data of the Suordakh event mafic intrusions; Table S5: Chemical and isotopic characteristics of the Suordakh event mafic intrusions.

Author Contributions: Conceptualization, A.K.K. and A.V.P.; formal analysis, K.R.C. and S.V.M.; investigation, K.R.C., A.D.S., S.V.M., and O.Y.L.; writing—original draft preparation, A.K.K.; writing-review and editing, A.V.P., K.R.C., R.E.E., and S.V.M.; visualization, A.D.S. and A.N.M.; funding acquisition, A.K.K., K.R.C., A.D.S., and R.E.E. All authors have read and agreed to the published version of the manuscript.

Funding: This research was funded by the Russian Science Foundation, grant number 18-17-00240. 
Acknowledgments: Comments by two anonymous reviewers significantly improved the manuscript. We are grateful to Galina G. Kazakova, Anatoliy P. Kropachev, and Mikhail A. Kalinin from A.P. Karpinsky Russian Geological Research Institute for research materials support and to Elena Morozova from University of Wyoming for image acquisition for geochronology.

Conflicts of Interest: The authors declare no conflict of interest.

\section{References}

1. Yan-Zhin-Shin, V.A. Tectonics of the Sette-Daban Horst Anticlinorium; Yakutian Branch of the Siberian Branch of Soviet Academy of Science Press: Yakutsk, Russia, 1983. (In Russian)

2. Parfenov, L.M. Continental Margins and Island Arcs of Mesozoides of Northeastern Asia; Nauka: Novosibirsk, Russia, 1984. (In Russian)

3. Prokopiev, A.V.; Parfenov, L.M.; Tomshin, M.D.; Kolodeznikov, I.I. Sedimentary cover of the Siberian platform and adjacent fold and thrust belts. In Tectonics, Geodynamics and Metallogeny of the Territory of the Republic of Sakha (Yakutia); Parfenov, L.M., Kuzmin, M.I., Eds.; MAIK Science/Interperiodika: Moscow, Russia, 2001; pp. 113-146. (In Russian)

4. Khudoley, A.K.; Guriev, G.A. Influence of syn-sedimentary faults on orogenic structure: Examples from the Neoproterozoic-Mesozoic east Siberian passive margin. Tectonophysics 2003, 365, 23-43. [CrossRef]

5. Natapov, L.M. (Ed.) State Geological Map of the Russian Federation. Scale 1:1,000,000; New Series; Sheet P-52,53-Yakutsk. Explanatory Note; VSEGEI Press: St. Petersburg, Russia, 1999. (In Russian)

6. Kazakova, G.G.; Vaskin, A.F.; Kropachev, A.P.; Scherbakov, O.I.; Prokopiev, A.V.; Khudoley, A.K.; Sharov, L.A.; Ivanova, T.K.; Kuzmin, V.K.; Zheleboglo, O.V.; et al. State Geological Map of the Russian Federation. Scale 1:1,000,000, 3rd ed.; Sheet P-54-Oimyakon; Verkhoyansk-Kolyma Series; Explanatory Note; VSEGEI Press: St. Petersburg, Russia, 2013. (In Russian)

7. Ernst, R.E. Large Igneous Provinces; Cambridge University Press: Cambridge, UK, 2014.

8. Khudoley, A.K.; Kropachev, A.P.; Heaman, L.; Zhuravlev, D.Z.; Guriev, G.A. Early Paleozoic magmatism of Sette-Daban, South Verkhoyansk, southeast Yakutia. Dokl. Earth Sci. 2001, 378, 392-395.

9. Chamberlain, K.R.; Schmitt, A.K.; Swapp, S.M.; Harrison, T.M.; Swoboda-Colberg, N.; Bleeker, W.; Peterson, T.D.; Jefferson, C.W.; Khudoley, A.K. In situ U-Pb SIMS (IN-SIMS) micro-baddeleyite dating of mafic rocks: Method with examples. Precambrian Res. 2010, 183, 379-387. [CrossRef]

10. Khudoley, A.K.; Prokopiev, A.V.; Chamberlain, K.R.; Ernst, R.E.; Jowitt, S.M.; Malyshev, S.V.; Zaitsev, A.I.; Kropachev, A.P.; Koroleva, O.V. Early Paleozoic mafic magmatic events on the eastern margin of the Siberian Craton. Lithos 2013, 174, 45-56. [CrossRef]

11. Berzin, N.A.; Distanov, E.G.; Tomurtogoo, O.; Prokopiev, A.V.; Timofeev, V.F.; Nokleberg, W.J. Neoproterozoic through Silurian metallogenesis and tectonics of Northeast Asia. In Metallogenesis and Tectonics of Northeast Asia; Chapter 5; Nokleberg, W.J., Ed.; U.S. Geol. Surv. Professional Paper: Reston, VA, USA, 2010; Volume 1765, pp. 5-1-5-71.

12. Cho, D.-L.; Lee, S.R.; Koh, H.J.; Park, J.-B.; Armstrong, R.; Choi, D.K. Late Ordovician volcanism in Korea constrains the timing for breakup of Sino-Korean craton from Gondwana. J. Asian Earth Sci. 2014, 96, 279-286. [CrossRef]

13. Kilian, T.M.; Swanson-Hysell, N.L.; Bold, U.; Crowley, J.; Macdonald, F.A. Paleomagnetism of the Teel basalts from the Zavkhan terrane: Implications for Paleozoic paleogeography in Mongolia and the growth of continental crust. Lithosphere 2016, 8, 699-715. [CrossRef]

14. Derakhshi, M.; Ghasemi, H.; Miao, L. Geochemistry and petrogenesis of Soltan Maidan basalts (E Alborz, Iran): Implications for asthenosphere-lithosphere interaction and rifting along the $\mathrm{N}$ margin of Gondwana. Chem. Erde 2017, 77, 131-145. [CrossRef]

15. Gonzalez-Menéndez, L.; Gallastegui, G.; Cuesta, A.; Heredia, N.; Rubio-Ordóñez, A. Petrogenesis of Early Paleozoic basalts and gabbros in the western Cuyania terrane: Constraints on the tectonic setting of the southwestern Gondwana margin (Sierra del Tigre, Andean Argentine Precordillera). Gondwana Res. 2013, 24, 359-376. [CrossRef]

16. Retallack, G.J. Late Ordovician Basalts of Sierra Del Tigre, Argentine Precordillera, and the Hirnantian Mass Extinction. November 2015 LIP of the Month 2015. Available online: http://www.largeigneousprovinces.org/ 15nov (accessed on 9 December 2020). 
17. Goodfellow, W.D.; Cecile, M.P.; Leybourne, M.I. Geochemistry, petrogenesis, and tectonic setting of lower Paleozoic alkalic and potassic volcanic rocks, Northern Canadian Cordilleran Miogeocline. Canad. J. Earth Sci. 1995, 32, 1236-1254. [CrossRef]

18. Courtillot, V. Mass extinctions in the last 300 million years: One impact and seven flood basalts? Isr. J. Earth Sci. 1994, 43, 255-266.

19. Ernst, R.E.; Youbi, N. How Large Igneous Provinces affect global climate, sometimes cause mass extinctions, and represent natural markers in the geological record. Palaeogeogr. Palaeoclimatol. Palaeoecol. 2017, 478, 30-52. [CrossRef]

20. Ernst, R.E.; Bond, D.P.G.; Zhang, S.-H.; Buchan, K.L.; Grasby, S.E.; Youbi, N.; El Bilali, H.; Bekker, A.; Doucet, L. Large Igneous Province Record Through Time and Implications for Secular Environmental Changes and Geological Time-Scale Boundaries. In Large Igneous Provinces: A Driver of Global Environmental and Biotic Changes; Ernst, R.E., Dickson, A.J., Bekker, A., Eds.; AGU and Wiley: Hoboken, NJ, USA, 2021; Chapter 1; Volume 255, pp. 3-26. [CrossRef]

21. Parfenov, L.M.; Prokopiev, A.V.; Gaiduk, V.V. Cretaceous frontal thrusts of the Verkhoyansk fold belt, eastern Siberia. Tectonics 1995, 14, 342-358. [CrossRef]

22. Prokopev, A.V.; Deikunenko, A.V. Deformational structures of the fold-thrust belts. In Tectonics, Geodynamics and Metallogeny of the Territory of the Republic of Sakha (Yakutia); Parfenov, L.M., Kuzmin, M.I., Eds.; MAIK Science/Interperiodika: Moscow, Russia, 2001; pp. 156-198. (In Russian)

23. Khudoley, A.K.; Prokopiev, A.V. Defining the eastern boundary of the North Asian craton from structural and subsidence history studies of the Verkhoyansk fold and thrust belt. In Whence the Mountains? Enquiries Into the Evolution of Orogenic Belts: A Volume in Honor of Raymond A. Price; Sears, J.W., Harms, T.A., Evenchick, C.A., Eds.; Geological Society of America: Boulder, CO, USA, 2007; Volume 433, pp. 391-410. [CrossRef]

24. Prokopiev, A.V.; Toro, J.; Hourigan, J.K.; Bakharev, A.G.; Miller, E.L. Middle Palaeozoic-Mesozoic boundary of the North Asian craton and the Okhotsk terrane: New geochemical and geochronological data and their geodynamic interpretation. Stephan Mueller Spec. Publ. Ser. 2009, 4, 71-84. [CrossRef]

25. Malyshev, S.V.; Khudoley, A.K.; Glasmacher, U.A.; Kazakova, G.G.; Kalinin, M.A. Constraining age of deformation stages in the south-western part of Verkhoyansk fold-and-thrust belt by apatite and zircon fission-track analysis. Geotectonics 2018, 52, 634-646. [CrossRef]

26. Starnikov, A.I.; Pushkar, N.N.; Chernobrovkina, G.A.; Grinenko, V.S.; Kirusenko, T.S.; Mozalevskiy, E.L.; Kovalev, L.N. Geological Map of Yakutia at Scale 1:500,000; The South Verkhoyansk Set (15 sheets); VSEGEI Press: St. Petersburg, Russia, 1995. (In Russian)

27. Khudoley, A.K.; Rainbird, R.H.; Stern, R.A.; Kropachev, A.P.; Heaman, L.M.; Zanin, A.M.; Podkovyrov, V.N.; Belova, V.N.; Sukhorukov, V.I. Sedimentary evolution of the Riphean-Vendian basin of southeastern Siberia. Precambrian Res. 2001, 111, 129-163. [CrossRef]

28. Rainbird, R.H.; Stern, R.A.; Khudoley, A.K.; Kropachev, A.P.; Heaman, L.M.; Sukhorukov, V.I. $\mathrm{U}-\mathrm{Pb}$ geochronology of Riphean supracrustal rocks from southeast Siberia and its bearing on the Laurentia-Siberia connection. Earth Planet. Sci. Lett. 1998, 164, 409-420. [CrossRef]

29. Kiselev, A.I.; Ernst, R.E.; Yarmolyuk, V.V.; Egorov, K.N. Radiating rifts and dyke swarms of the middle Paleozoic Yakutsk plume of eastern Siberian craton. J. Asian Earth Sci. 2012, 45, 1-16. [CrossRef]

30. Savelev, A.D.; Malyshev, S.V.; Savatenkov, V.M.; Ignatov, D.D.; Kuz'kina, A.D. Meso-Neoproterozoic Mafic Sills along the South-Eastern margin of the Siberian Craton, SE Yakutia: Petrogenesis, Tectonic and Geochemical features. Minerals 2020, 10, 805. [CrossRef]

31. Ernst, R.E.; Rodygin, S.A.; Grinev, O.M. Age Correlation of Large Igneous Provinces with Devonian biotic crises. Glob. Planet. Chang. 2020, 185, 103097. [CrossRef]

32. Yan-Zhin-Shin, V.A. State Geological Map of the USSR, Scale 1:200,000; sheet P-53-XXIV (Akra). Maya Series; Aerogeologiya Press: Leningrad, Russia, 1974. (In Russian)

33. Yan-Zhin-Shin, V.A. State Geological Map of the USSR, Scale 1:200,000; sheet P-53-XXIX (Akra). Maya Series; Aerogeologiya Press: Leningrad, Russia, 1976. (In Russian)

34. Starnikov, A.I. State Geological Map of the Russian Federation, Scale 1:200,000; Sheet P-53-XXX; Maya Series; VSEGEI Press: St. Petersburg, Russia, 1993. (In Russian) 
35. Ludwig, K.R. ISOPLOT for MS-DOS, a Plotting and Regression Program for Radiogenic-Isotope Data, for IBM-PC Compatible Computers, Version 2.75; U.S. Geological Survey, Open-File Report: Reston, VA, USA, 1991; pp. 91-445.

36. Ludwig, K.R. On the treatment of concordant uranium-lead ages. Geochim. Cosmochim. Acta 1998, 62, 665-676. [CrossRef]

37. Steshenko, E.N.; Bayanova, T.B.; Serov, P.A. The Paleoproterozoic Kandalaksha-Kolvitsa Gabbro-Anorthosite Complex (Fennoscandian Shield): New U-Pb, Sm-Nd, and Nd-Sr (ID-TIMS) isotope data on the age of formation, metamorphism, and geochemical features of zircon (LA-ICP-MS). Minerals 2020, 10, 254. [CrossRef]

38. Yoneda, S.; Shimizu, H.; Kunimaru, T.; Takahashi, K.; Yanagi, T.; Nakano, T.; Fujimaki, H.; Shinjo, R.; Asahara, Y.; Tanimizu, M.; et al. JNdi-1: A neodymium isotopic reference in consistency with LaJolla neodymium. Chem. Geol. 2000, 168, 279-281. [CrossRef]

39. Malyshev, S.V.; Khudoley, A.K.; Prokopiev, A.V.; Ershova, V.B.; Kazakova, G.G.; Terentyeva, L.B. Source rocks of Carboniferous-Lower Cretaceous terrigenous sediments of the northeastern Siberian Platform: Results of Sm-Nd isotope-geochemical studies. Russ. Geol. Geophys. 2016, 57, 421-433. [CrossRef]

40. Jacobsen, S.; Wasserburg, G. Sm-Nd isotopic evolution of chondrites and achondrites. Earth Planet. Sci. Lett. 1984, 67, 137-150. [CrossRef]

41. Prokopiev, A.V.; Khudoley, A.K.; Koroleva, O.V.; Kazakova, G.G.; Lokhov, D.K.; Malyshev, S.V.; Zaitsev, A.I.; Roev, S.P.; Sergeev, S.A.; Berezhnaya, N.G.; et al. The Early Cambrian bimodal magmatism in the northeastern Siberian Craton. Russ. Geol. Geophys. 2016, 57, 155-175. [CrossRef]

42. Le Bas, M.J.; Le Maitre, R.W.; Streckeisen, A.; Zanettin, B. A Chemical Classification of Volcanic Rocks Based on the Total Alkali-Silica Diagram. J. Petrol. 1986, 27, 745-750. [CrossRef]

43. Irvine, T.N.; Baragar, W.R.A. A guide to the chemical classification of the common volcanic rocks. Canad. J. Earth Sci. 1971, 8, 523-548. [CrossRef]

44. Winchester, J.A.; Floyd, P.A. Geochemical discrimination of different magma series and their differentiation products using immobile elements. Chem. Geol. 1977, 20, 325-343. [CrossRef]

45. Polyansky, O.P.; Prokopiev, A.V.; Koroleva, O.V.; Tomshin, M.D.; Reverdatto, V.V.; Selyatitsky, A.Y.; Travin, A.V.; Vasiliev, D.A. Temporal correlation between dyke swarms and crustal extension in the middle Palaeozoic Vilyui rift basin, Siberian platform. Lithos 2017, 282-283, 45-64. [CrossRef]

46. Shervais, J.W. Ti-V plots and the petrogenesis of modern and ophiolitic lavas. Earth Planet. Sci. Lett. 1982, 59, 101-118. [CrossRef]

47. Kuno, H. Differentiation of basalt magmas. In Basalts: The Poldervaart Treatise on Rock of Basaltic Composition; Hess, H.H., Poldervaart, A., Eds.; Interscience: New York, NY, USA, 1968; Volume 2, pp. 632-688.

48. Pearce, J.A.; Stern, R.J.; Bloomer, S.H.; Fryer, P. Geochemical mapping of the Mariana arc-basin system: Implications for the nature and distribution of subduction components. Geochem. Geophys. Geosyst. 2005, 6, 1-27. [CrossRef]

49. Sun, S.; McDonough, W. Chemical and isotopic systematics of ocean basalts: Implications for mantle composition and processes, in Magmatism in the Ocean Basins. Geol. Soc. Spec. Publ. 1989, 42, 313-345. [CrossRef]

50. Ivanov, A.V.; Demonterova, E.I.; Rasskazov, S.V.; Yasnygina, T.A. Low-Ti melts from the southeastern Siberian Traps Large Igneous Province: Evidence for a water-rich mantle source? J. Earth Syst. Sci. 2008, 117. [CrossRef]

51. Jourdan, F.; Bertrand, H.; Schärer, U.; Blichert-Toft, J.; Féraud, G.; Kampunzu, A.B. Major and trace element and $\mathrm{Sr}, \mathrm{Nd}, \mathrm{Hf}$, and $\mathrm{Pb}$ isotope compositions of the Karoo large igneous province, Botswana-Zimbabwe: Lithosphere vs Mantle Plume Contribution. J. Petrol. 2007, 48, 1043-1077. [CrossRef]

52. Xia, L.-Q. The geochemical criteria to distinguish continental basalts from arc related ones. Earth Sci. Rev. 2014, 139, 195-212. [CrossRef]

53. Zindler, A.; Hart, S.R. Chemical geodynamics. Annu. Rev. Earth Planet. Sci. 1986, 14, 493-571. [CrossRef]

54. Petrov, O.V. (Ed.) Geological Map of Russia and Adjoining Water Areas, Scale 1:2,500,000; VSEGEI Press: St. Petersburg, Russia, 2012. (In Russian)

55. Bryan, S.; Ernst, R.E. Revised definition of Large Igneous Provinces (LIPs). Earth Sci. Rev. 2008, 86, 175-202. [CrossRef] 
56. Cluzel, D. Ordovician bimodal magmatism in the Ogcheon belt (South Korea): Intracontinental rift-related volcanic activity. J. Southeast Asian Earth Sci. 1992, 7, 195-209. [CrossRef]

57. Delabroye, A.; Vecoli, M. The end-Ordovician glaciation and the Hirnantian Stage: A global review and questions about Late Ordovician event stratigraphy. Earth Sci. Rev. 2010, 98, 269-282. [CrossRef]

58. Melchin, M.J.; Mitchell, C.E.; Holmden, C.; Štorch, P. Environmental changes in the Late Ordovician-early Silurian: Review and new insights from black shales and nitrogen isotopes. Geol. Soc. Am. Bull. 2013, 125, 1635-1670. [CrossRef]

59. Harper, D.A.T.; Hammarlund, E.U.; Rasmussen, C.M.Ø. End Ordovician extinctions: A coincidence of causes. Gondwana Res. 2014, 25, 1294-1307. [CrossRef]

60. Wang, G.; Zhan, R.; Percival, I.G. The end-Ordovician mass extinction: A single-pulse event? Earth Sci. Rev. 2019, 192, 15-33. [CrossRef]

61. Rampino, M.R.; Caldeira, K.; Prokoph, A. What causes mass extinctions? Large asteroid/comet impacts, flood-basalt volcanism, and ocean anoxia-Correlations and cycles. In 250 Million Years of Earth History in Central Italy: Celebrating 25 Years of the Geological Observatory of Coldigioco; Koeberl, C., Bice, D.M., Eds.; Geological Society of America: Boulder, CO, USA, 2019; Volume 542, pp. 271-302. [CrossRef]

62. Chen, J.; Xu, Y.-G. Permian Large Igneous Provinces and Their Paleoenvironmental Effects. In Large Igneous Provinces: A Driver of Global Environmental and Biotic Changes; Ernst, R.E., Dickson, A.J., Bekker, A., Eds.; AGU and Wiley: Hoboken, NJ, USA, 2021; Chapter 18; Volume 255, pp. 417-434. [CrossRef]

63. Kravchinsky, V.A. Paleozoic large igneous provinces of Northern Eurasia: Correlation with mass extinction events. Glob. Planet. Chang. 2012, 86-87,31-36. [CrossRef]

64. Cohen, K.M.; Finney, S.C.; Gibbard, P.L.; Fan, J.-X. The ICS International Chronostratigraphic Chart. Episodes 2013, 36, 199-204. [CrossRef]

65. Parfenov, L.M.; Oxman, V.S.; Prokopiev, A.V.; Timofeev, V.F.; Trtiakov, F.F.; Trunilina, V.A.; Deikunenko, A.V. Terrane collage of the Verkhoyansk-Kolyma orogenic area. In Tectonics, Geodynamics and Metallogeny of the Territory of the Republic of Sakha (Yakutia); Parfenov, L.M., Kuzmin, M.I., Eds.; MAIK Science/Interperiodika: Moscow, Russia, 2001; pp. 199-255. (In Russian)

66. Pavlov, V.E.; Manukyan, A.M.; Sharkovskii, M.B.; Levashova, N.M. 1st paleomagnetic results for the Riphean of Okhotsk Massive. Dokl. Akad. Nauk SSSR 1991, 317, 688-692. (In Russian)

67. Stone, D.B.; Minyuk, P.; Kolosev, E. New paleomagnetic paleolatitudes for the Omulevka terrane of northeast Russia: A comparison with the Omolon terrane and the eastern Siberian platform. Tectonophysics 2003, 377, 55-82. [CrossRef]

68. Shpikerman, V.I. Pre-Cretaceous Minerageny of North-Eastern Asia (NEISRI, Far Eastern Branch of the Russian); Academy of Science Press: Magadan, Russia, 1998. (In Russian)

69. Surmilova, E.P.; Maximova, G.A. State Geological Map of the USSR, Scale 1:200,000; Sheet Q-53-XXIX,XXX (Mouth of Bulkut River). Srednekolymsk Series. Explanation Text; Aerogeologiya Press: Moscow, Russia, 1987. (In Russian)

70. Sychev, S.N.; Khudoley, A.K.; Lebedeva, O.Yu.; Rogov, A.V.; Sokolov, S.D.; Chamberlain, K.R.; Maklashin, V.S.; Lvov, P.A. Silurian granitoid magmatism of the Rassokha Terrane (North-East Russia). Dokl. Earth Sci. 2020, 494, 762-766. [CrossRef]

71. Kuzmin, V.K.; Belyatskiy, B.V.; Naumov, M.V. New isotopic-geochemical data on the Late Ordovician age of granitoids from the western part of the Okhotsk massif (Upper Maya uplift). Russ. J. Reg. Geol. Metallog. 2003, 19, 101-105. (In Russian)

72. Sokolov, S.D. Tectonics of Northeast Asia: An overview. Geotectonics 2010, 44, 493-509. [CrossRef]

73. Bryan, S.E.; Ferrari, L. Large Igneous Provinces and Silicic Large Igneous Provinces: Progress in our understanding over the last 25 years. Geol. Soc. Am. Bull. 2013, 125, 1053-1078. [CrossRef]

74. Mustafaev, A.A.; Gertner, I.F. Isotope-geochemical (Sm-Nd, Rb-Sr, REE, HFSE) composition of the University foidolite-gabbro pluton, Kuznetsk Alatau ridge, Siberia. Vestn. Spbsu. Earth Sci. 2020, 65. [CrossRef]

75. Fitton, J.G.; Saunders, A.D.; Norry, M.J.; Hardarson, B.S.; Taylor, R.N. Thermal and chemical structure of the Iceland plume. Earth Planet. Sci. Lett. 1997, 153, 197-208. [CrossRef]

76. Pearce, J.A. Geochemical fingerprinting of oceanic basalts with applications to ophiolite classification and the search for Archean oceanic crust. Lithos 2008, 100, 14-48. [CrossRef]

77. Condie, K.C. High field strength element ratios in Archean basalts: A window to evolving sources of mantle plumes? Lithos 2005, 79, 491-504. [CrossRef] 
78. Hawkesworth, C.J.; Turner, S.P.; McDermott, F.; Peate, D.W.; van Calsteren, P. U-Th Isotopes in arc magmas: Implications for element transfer from the subducted crust. Science 1997, 276, 551-555. [CrossRef]

79. Zhang, M.; Guo, Z.; Cheng, Z.; Zhang, L.; Liu, J. Late Cenozoic intraplate volcanism in Changbai volcanic field, on the border of China and North Korea: Insights into deep subduction of the Pacific slab and intraplate volcanism. J. Geol. Soc. Lond. 2015, 172, 648-663. [CrossRef]

80. Ivanov, A.V.; Mukasa, S.B.; Kamenetsky, V.S.; Ackerson, M.; Demonterova, E.I.; Pokrovsky, B.G.; Vladykin, N.V.; Kolesnichenko, M.V.; Litasov, K.D.; Zedgenizov, D.A. Volatile concentrations in olivine-hosted melt inclusions from meimechite and melanephelinite lavas of the Siberian Traps Large Igneous Province: Evidence for flux-related high-Ti, high-Mg magmatism. Chem. Geol. 2018, 483, 442-462. [CrossRef]

81. Pearce, J.; Ernst, R.E.; Peate, D.; Rogers, C. LIP Printing: Use of Immobile Element Proxies to Characterize Large Igneous Provinces in the Geologic Record. Lithos 2021. submitted.

82. Stacey, J.S.; Kramers, J.D. Approximation of terrestrial lead isotope evolution by a two-stage model. Earth Planet. Sci. Lett. 1975, 26, 207-221. [CrossRef]

Publisher's Note: MDPI stays neutral with regard to jurisdictional claims in published maps and institutional affiliations.

(C) 2020 by the authors. Licensee MDPI, Basel, Switzerland. This article is an open access article distributed under the terms and conditions of the Creative Commons Attribution (CC BY) license (http://creativecommons.org/licenses/by/4.0/). 